К. В. Вершинин

Институт российской истории РАН

(Россия, Москва)

versh-kv@yandex.ru

\title{
НЕИЗВЕСТНЫЙ ДРЕВНЕРУССКИЙ ТОЛКОВЫЙ ПЕРЕВОД (КАТЕНА НА ПСАЛТЫРЬ)
}

Статья вводит в научный оборот ранее не исследованный памятник славянской переводной литературы - катену на Псалтырь, сохранившуюся в шести списках XV-XVI в. (в том числе трех - в составе Великих миней четьих митрополита Макария). Точный греческий архетип памятника неизвестен; объем перевода также не ясен, так как дошедшие до нас списки обрываются после Пс. 76 или на середине Пс. 84. Катена включает в себя отрывки четырех произведений: «Толкования на Псалмы» Феодорита Кирского (CPG 6202), трактата «О надписании Псалмов» и «Большого комментария на Псалмы» Исихия Иерусалимского (CPG 6552, 6554), «Краткого комментария на Псалмы» Псевдо-Исихия (CPG 6553). В частности, «Большой комментарий» представлен почти полным текстом толкований на Пс. 51-84, что, несомненно, должно учитываться в исследованиях этого важного сочинения, греческий оригинал которого сохранился в единичных фрагментарных списках. Анализ текста показывает, что катена была переведена русскими книжниками в конце XI - начале XII в. По языку памятник близок к другим древнерусским толковым переводам, прежде всего Толковому Евангелию Феофилакта Болгарского (Охридского) и Толковому Апостолу.

Ключевые слова: Исихий Иерусалимский, Феодорит Кирский, Псалтырь, катены, экзегетика, древнерусская литература, славянская переводная литература

В рукописи РГБ, Прян. 8 автором этих строк была обнаружена неизученная толковая Псалтырь. Это рукопись объемом 292 листа ${ }^{1}$, в лист, в два столбца, датируемая серединой XVI в. ${ }^{2}$ и имеющая признаки новгородского происхождения - pe-

\footnotetext{
${ }^{1}$ По ошибке счетчика листы, следующие за л. 129, обозначены как 230, 231 и т. д. Также два листа подряд обозначены как л. 11. Для удобства, однако, всюду сохраняем текущую нумерацию листов.

${ }^{2}$ Филигрань: рука под цветком, близкая к Брике 10786 (1544-1545 гг.).
} 


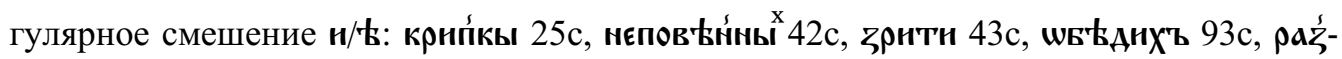
九ъчнымъ $113 \mathrm{~d}$ и мн. др., а также единичные случаи цоканья: въ цив̈цн сємь $103 \mathrm{a}^{3}$.

Содержащийся в манускрипте текст состоит из двух разнородных частей, граница между которыми проходит по Пс. 84:10 (л. 306a). До второй половины указанно-

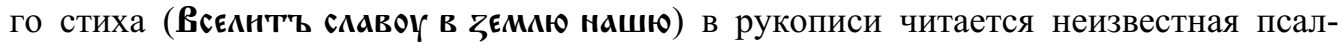
тырная катена, о которой пойдет речь ниже. Толкования на последующие псалмы (до Пс. 151 включительно) и на библейские песни выписаны из полного перевода «Краткого комментария» Псевдо-Исихия Иерусалимского (CPG 6553) ${ }^{4}$, широко распространенного в славянской книжности и надписывавшегося именем Афанасия Александрийского ${ }^{5}$. Очевидно, по этому толкованию был восполнен незавершенный перевод или дефектный протограф.

Отрывок того же памятника был обнаружен в рукописи $1430-\mathrm{x}-1440$-х гг. ${ }^{6}$ РНБ, Кир.-Бел. 8/133 (в лист, в один столбец), где помещены толкования на Пс. 53-84 (сама рукопись при этом утрат не имеет). Этот список, также содержащий орфографические «новгородизмы», не только является старшим из известных, но и отражает более ранний этап истории текста, чем Прян. 8: здесь по Псевдо-Исихию восполнены лишь толкования на окончание Пс. 84 - стихи 10 (вторая половина) и 11-14, остальные псалмы отсутствуют ${ }^{7}$.

Наконец, тот же самый памятник включен (наряду с толковой Псалтырью Феодорита Кирского в древнеболгарском переводе и толковой Псалтырью Брунона Вюрцбургского в переводе Дмитрия Герасимова 1535-1536 гг.) под 20 августа в состав Софийского (РГАДА, Обол. 161, л. 200a-317b) и Успенского (ГИМ, Син. 997, л. 299a-450b) комплектов Великих миней четьих ${ }^{8}$. В августовском томе Царского списка (ГИМ, Син. 183) все три толкования на Псалтырь теперь отсутствуют, однако существует рукопись середины XVI в. (РГБ, Егор. 12), где они читаются подряд. Очевидно, она представляет собой фрагмент, изъятый из Царского списка ${ }^{9}$. Успенская

\footnotetext{
${ }^{3}$ См. также: [Вершинин 2017: 23-24].

${ }^{4}$ Принадлежность «Краткого комментария» Исихию крайне сомнительна и оспаривается современной наукой [Ткачев 2011: 259].

${ }^{5}$ Старшие списки относятся к XI в. Существует фототипическое издание болгарской рукописи XIII в.: [Болонски Псалтир 1968], которая легла также в основу наборного издания [Jagić 1907].

${ }^{6}$ Датировка по филиграням принадлежит Г. М. Прохорову и вписана им в 1987 г. в лист использования.

${ }^{7}$ Рукопись Кир.-Бел. 8/133 не могла быть привлечена к исследованию в полном объеме, так как мы ознакомились с ней уже после сдачи настоящей статьи в печать. Еще позже нашелся список РНБ Солов. 1042/1151, XVI в., л. 1-175об., с толкованиями на Пс. 1-63:1 (конец оборван).

${ }^{8}$ См., напр., описание Успенского списка: [Иосиф 1892: 423-424]; содержание текста здесь не определено.

9 Описание см.: [Анисимова 2017: 41-44]. В конце ХІХ в. рукопись была доступна С. А. Белокурову, который нашел в ней: 1) запись Афанасия Скиады (Videtur scriptus seculo 16), позволяющую думать, что в XVIII в. манускрипт находился в Синодальной библиотеке, и 2) за-
} 
и Егоровская рукописи повторяют все отмеченные в настоящей статье чтения и прочие особенности Софийского списка, поэтому в дальнейшем мы ими пренебрегаем.

В ВМЧ граница катены с фрагментом полного перевода Псевдо-Исихия пролегает ранее, чем в Прян. 8 и Кир.-Бел. 8/133 - после Пс. 76 (см.: РГАДА, Обол. 161, л. $273 \mathrm{~d}$; здесь и далее обращаюсь к этому тому из Софийского комплекта ВМЧ). Отсюда можно заключить, что в протографе ВМЧ фрагмента с толкованиями на Пс. 76-84:10 не было - видимо, по причине утраты листов. Косвенным тому подтверждением служат мелкие лакуны в начале толкования на Пс. 75, оставленные писцом ВМЧ в надежде на их заполнение (очевидно, один из последних листов в антиграфе был оборван). Соседние с лакунами слова частично искажены. В Прян. 8 и Кир.-Бел. 8/133 все соответствующие места сохранились неповрежденными, например (лакуны обозначаются точками):

\begin{tabular}{|c|c|}
\hline Прян. 8, л. 270с & Обол. 161 , л. $271 \mathrm{~b}$ \\
\hline 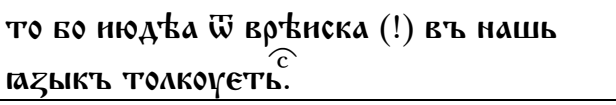 & 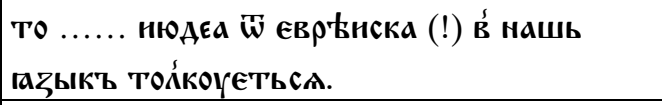 \\
\hline $\begin{array}{l}\text { व ЕЖЕ ПОСААТН НЦРОАА. КАКО ПО НМЕНН ЕГО } \\
\text { НАВЫКАН }\end{array}$ & $\begin{array}{l}\text { Ф ЕЖЕ ПО ПАОТН. ........ КАКО ПО НМЕНН ЕГО } \\
\text { НАВЫКАН }\end{array}$ \\
\hline 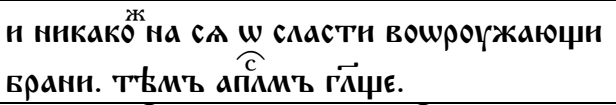 & 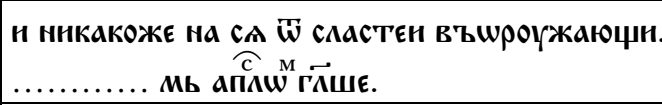 \\
\hline 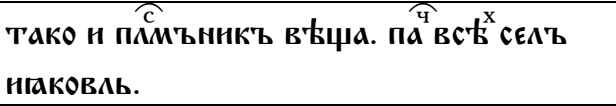 & 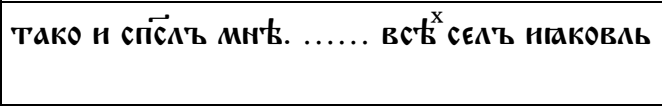 \\
\hline ПОНЕ СНW' СМОТРНАНџЕ ТОАКУЕТ'ТА. & ПОНЕЖЕ СНWНЪ СЪ .......... ЕТСА \\
\hline 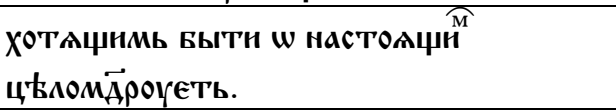 & ХОТАџн БЫТН .................. MоУАроУЕТЬ \\
\hline
\end{tabular}

пись на ломаной латыни (Ista psalteriu[m] magnae Regi), на основании который ученый допускал принадлежность его в XVI в. к библиотеке Ивана Грозного [Белокуров 1898: 332]. Еще из одной записи известно, что рукопись была создана в пригороде Новгорода, в Никольском монастыре «Легоща заполья»; некоторые ее филиграни тождественны тем, что имеются в Царском списке ВМЧ [Анисимова 2017: 43-44]. Формат рукописи тот же (большой александрийский лист); совпа-

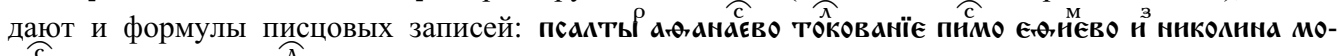

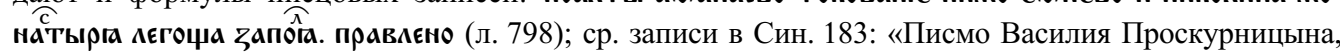
правлено»; «Писмо Постниково с Нутные улицы, правлено» и т. п. [Протасьева 1970: 207]. В ог-

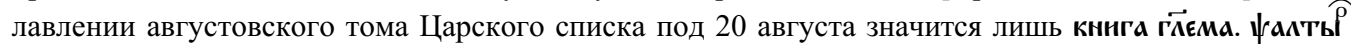
толковал. алөданасїа вєлнкаго (л. 5), но на нижнем поле сделана приписка (другим почерком): зА中

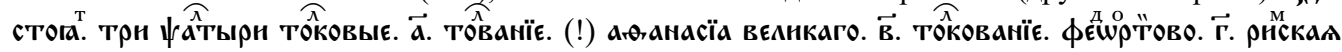

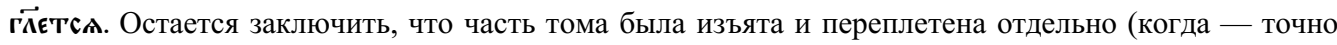
неизвестно, но, видимо, не в процессе подготовки тома, а позже). Причиной могло быть не только тематическое единство текстов, но и неудобство пользования книгой: в полном виде августовский том был наиболее объемным из всех (более 1800 листов). 
Между рукописями есть и другие различия. В ВМЧ большинство первоначальных толкований из катены на Пс. 1 заменены на тексты из «Краткого комментария» Псевдо-Исихия (из полного славянского перевода). Объяснить это можно только тем, что в кодексе, который использовали составители ВМЧ, были повреждены также один или два листа в начале. Но и в начале Прян. 8 есть поздние дополнения: рукопись открывается «Молитвой починающей Псалтырь», молитвами Езекии и Манассии из полного перевода Псевдо-Исихия и притчей о еже и змее, которая часто сопровождает этот перевод в русских списках ${ }^{10}$. Список ВМЧ не содержит указанных статей, но в нем, в отличие от Прян. 8, перед Пс. 1 читается предисловие (его происхождение осталось нам неизвестным), объясняющее древнюю иудейскую традицию деления Псалтыри на пять частей (Обол. 161, л. 200а). Список Кир.-Бел. 8/133 не содержит никаких других текстов, кроме толкований на псалмы.

Можно полагать, что все известные к настоящему времени списки памятника восходят, так или иначе, к одной-единственной древней новгородской рукописи. Неизвестно, обрывался ли на стихе Пс. 84:10 переведенный греческий текст (то есть перевод был изначально неполон по отношению к Псалтыри) или этот обрыв произошел в русской рукописной традиции. Но, во всяком случае, Кир-Бел. 8/133 и Прян. 8 отражают древний манускрипт в его более комплектном виде. До составителей ВМЧ он дошел уже в поврежденном состоянии (или им был доступен список с него, уже потерявшего листы).

Обратимся к содержанию новооткрытого памятника. В нем выделяются две части: толкования на Пс. 1-50 и на Пс. 51-84:10 (в ВМЧ - 76). Толкования на Пс. 1-50 представляют собой компиляцию из Феодорита Кирского («Толкование на Псалмы» CPG 6202), Исихия Иерусалимского («О надписании Псалмов» CPG 6552) ${ }^{11}$ и Псевдо-Исихия («Краткий комментарий» CPG 6553). При этом из Феодорита, сочинение которого имеет огромный объем, заимствуются лишь отрывки, часто небольшие; из менее пространного Псевдо-Исихия часто берутся целиком комментарии на тот или иной стих; наконец, схолии Исихия, трактат которого - самый краткий из трех, обычно приводятся целиком.

В надписаниях фрагментов греческих авторов прослеживается определенная иерархия. После того или иного стиха Псалтыри (или нескольких кряду) следуют в первую очередь толкования Феодорита, которые почти никогда не надписываются (указание на авторство Феодорита встречается лишь единожды и с ошибкой: өөєш⿱ в Прян. 8 , л. $14 \mathrm{~d}$; в ВМЧ пропущено). Затем читаются отрывки трактата Исихия «О надписании Псалмов» - обычно с надписаниями їсю или ӥсюхїн (иногда с иска-

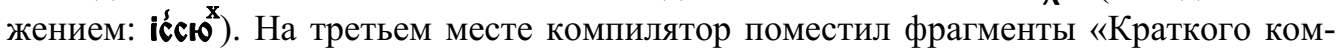
ментария» Псевдо-Исихия: они сопровождаются анонимными обозначениями инъ

${ }^{10}$ Притча издана: [Востоков 1842: 469].

11 Памятник неосновательно приписан Афанасию Александрийскому в XVIII в. кардиналом Н. Антонелли [Devreesse 1970: 215], издание которого перепечатано в «Патрологии» Ж.-П. Миня [PG 27: 649-1344]. 
или ннъ, что находит соответствие в греческих катенах [Dorival 1995: 58]. Если фрагменты Феодорита отсутствуют, то на первом месте стоят отрывки Исихия как правило, без надписаний; за ними - фрагменты Псевдо-Исихия с обычными надписаниями нмъ/нмъ. В некоторых случаях приводятся только толкования Псевдо-Исихия, которые в этом случае не надписаны.

Точное греческое соответствие этой катене неизвестно или, по крайней мере, не описано в литературе. Существует катена, составленная преимущественно из тех же трех источников — «Толкования на Псалмы» Феодорита, трактата «О надписании Псалмов» Исихия и «Краткого комментария» Псевдо-Исихия [Dorival 1995: 54-113], однако в ней использованы другие отрывки. Так, например, в нашем памятнике Пс. 11 (Обол. 161, л. 207c-208a) сопровождается следующим набором толкований ${ }^{12}$ : Феодорит, «Толкование на Псалмы», 11:2-3, 11:5-9; Исихий, «О надписании Псалмов», 10:0 (!), 11:1-7, 11:10, 11:13-16, 11:20; Псевдо-Исихий, «Краткий комментарий на Псалмы», 11:2, 11:5, 11:7, 11:9. В упомянутой греческой катене подборка иная: Исихий, «О надписании Псалмов», 11:0, 11:1-3, 11:6, 11:8-9, 11:7, 11:10-11, 11:13-18; Феодорит, «Толкование на Псалмы», 11:3, 11:2, 11:3, 11:5-6, 11:8-9; Псевдо-Исихий, «Краткий комментарий на Псалмы», 11:2-9 [Там же: 59-60]. Что особенно важно, в греческой катене основным автором выступает Исихий, в новооткрытом же переводном тексте, как уже было сказано, - Феодорит. Представление о составе катены можно также составить из приложения к статье, где публикуется толкование на Пс. 14.

Сличение отрывков Феодорита с полным славянским текстом его толкований на 150 псалмов ${ }^{13}$ не оставляет сомнений в том, что перед нами разные переводы. В частности, имеются случаи, когда наша катена, в отличие от полного перевода Феодо-

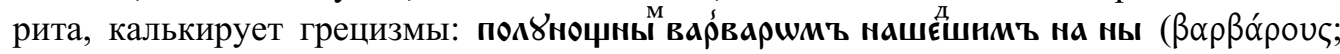
Прян. 8, л. 25а; Обол. 161, л. 211d). Ср. в полном переводе: сћверьск४ю чадь нашєేш४ на ны (РГБ, МДА 24, л. 36об.). В то же время переводчиком постоянно привлекался полный славянский текст Псевдо-Исихия. Например:

\begin{tabular}{|c|c|}
\hline [Болонски Псалтир 1968: 29] & Обол. 161 , л. 200c \\
\hline 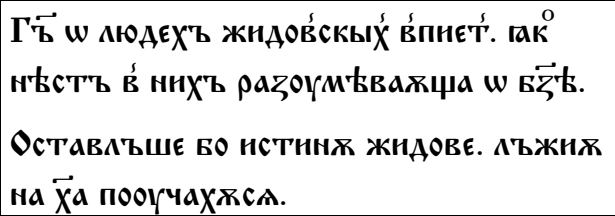 & 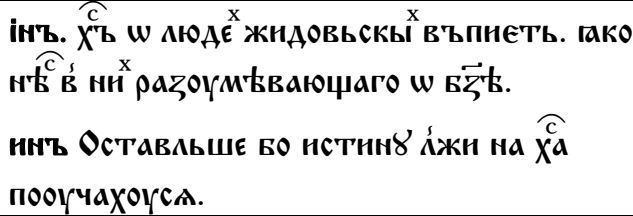 \\
\hline
\end{tabular}

${ }^{12}$ В случае с Феодоритом и Псевдо-Исихием даем номера толкуемых стихов, невзирая на объем заимствования; нумерация схолий трактата Исихия «О надписании Псалмов» заимствована из [PG 27: 649-1344], кроме нуля, которым мы обозначаем комментарий на надписание псалма.

${ }^{13}$ Считается, что этот перевод «обрывается на 144-м псалме» [Алексеев 1999: 166], остаток же восполнен по Псевдо-Афанасию (= Псевдо-Исихию). Так обстоит дело в большинстве рукописей [Погорелов 1910: 85-92], но можно указать по меньшей мере один (неизвестный В. А. Погорелову) список, где толкования Феодорита на псалмы доведены до конца: РГБ, Рогож. 444 (третья четверть XV в.). 
Особый интерес представляют фрагменты подлинного трактата Исихия «О надписании Псалмов», о славянской традиции которого до сих пор ничего не было известно.

Пс. 51-84:10 (в ВМЧ - Пс. 51-76) сопровождаются текстом «Большого комментария» Исихия Иерусалимского (CPG 6554), сам греческий оригинал которого безусловная редкость. Отрывки «Большого комментария» включались в катены, но рукописи прямой традиции единичны и отрывочны [Devreesse 1970: 250-261]. Уже одного этого факта достаточно, чтобы убедиться в особой ценности рассматриваемого перевода, который, несомненно, должен быть учтен при подготовке отсутствующего до сих пор критического издания греческого оригинала «Большого комментария».

Важно, что ни в одной из греческих рукописей не представлено набора толкуемых псалмов, содержащегося в славянском переводе (интересно, впрочем, что рукописи Vat. gr. 525, XI в. и Vat. gr. 1223, Х в. начинаются, как и славянский перевод «Большого комментария», с Пс. 51). При этом особую ценность приобретают рукописи Кир.-Бел. 8/133 и Прян. 8, так как читающиеся в них толкования на Пс. 77-84 сохранились в единственном греческом манускрипте - Оксфорд, Бодлеанская библиотека, Roe 13 (из собрания Томаса Роy) ${ }^{14}$.

Нужно, однако, заметить, что толкования на надписания псалмов, присутствующие в «Большом комментарии» Исихия, в переводном тексте заменены на извлечения из трактата «О надписании Псалмов». В очень редких случаях вставки из того же трактата сделаны в комментариях на сами псалмы. Например, под стихом Пс. 76:21 читаем: нсю. Въ властн сна твоего монсђн адронъ. въ того тоќкоцєтасл... (Прян. 8, л. 276b; то же в Обол. 161, л. 273c-d), что соответствует грече-

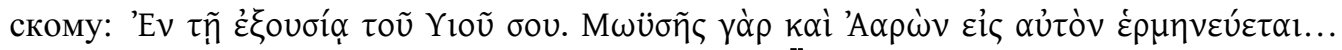
[PG 27: 967]. Судя по наличию надписания нсю, составитель толковой Псалтыри (или славянский переводчик?) не считал «Большой комментарий» (в отличие от комментария «О надписании Псалмов») произведением Исихия. Аналогичная картина наблюдается в доступной греческой традиции, где «Большой комментарий» анонимен либо, как в рукописи Roe 13, приписывается Иоанну Златоусту.

Так как «Большой комментарий» Исихия представлен в славянской версии в несокращенном виде, а не в извлечениях (если не считать только что упомянутого обстоятельства), то часть толковой Псалтыри, охватывающую Пс. 51-84:10, трудно

\footnotetext{
${ }^{14}$ Рукопись содержит толкования на Пс. 77-107, 118 и написана в 1284/1285 г. в Галесийском монастыре близ Эфеса по заказу «всечестного отца нашего иеро[монаха] кир Галактиона Слепого» [Coхе 1969: 466] — очевидно, того самого, что был лишен зрения по приказу Михаила VIII Палеолога наряду с другими противниками унии [Foss 1979: 129; Бърлиева 2000: 59]. Толкования на Пс. 77-99 опубликованы по рукописи Roe 13 Б. Монфоконом и перепечатаны Ж.-П. Минем [PG 55: 711-784]. Другие отрывки прямой рукописной традиции «Большого комментария» не изданы; фрагменты из катен см.: [PG 93: 1180-1340].
} 
считать катеной в строгом смысле слова. Вероятно, мы имеем дело с соединением нескольких разных источников на греческой (или славянской?) почве. Такой вывод хорошо соотносится с тем, что «классическая» катена обрывается после Пс. 50: греческие катены на Псалтырь нередко бытовали в виде трех томов (Пс. 1-50; 51-100; 101-150/151). Можно думать, что анонимному византийскому компилятору (или славянскому переводчику?) был доступен один том подобной катены, который он дополнил фрагментами двух трактатов Исихия.

Язык перевода первой (Пс. 1-50) и второй (Пс. 51-84:10) частей текста одинаков и, следовательно, был совершен в одно и то же время. В памятнике обнаруживаются русизмы (а также заимствования, характерные для древнерусского языка), некоторые из них - в составе псалтырных стихов. Приведем все соответствующие места:

1. доума 'совет', Аоуматн 'совещаться'. В этих значениях лексемы известны только восточным славянам [Пичхадзе 2011: 111-112]. В тексте имеется четыре случая их употребления: а) в толковании Феодорита Кирского на Пс. 9:27 (в полном тексте греческого оригинала — 9:28): и ве жнвоть свон нмать на ннцаА догмаА (Прян. 8, л. 14c) ${ }^{15}$; в ВМЧ искажено: на ннщал догма (!) (Обол. 161, л. 206с) — каі

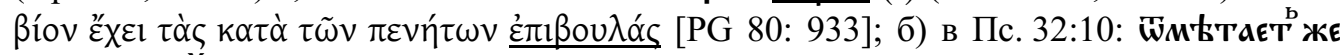

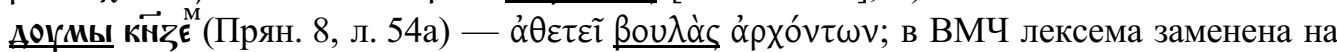
съвҺты (Обол. 161, л. 224d); в) в толковании Исихия на надписание Пс. 51: протнв́ныА снды. догмають съ дьАволомъ (Прян. 8, л. 96d; то же в Обол. 161,

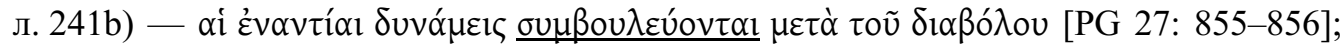

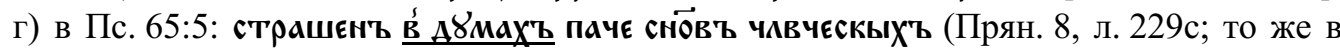

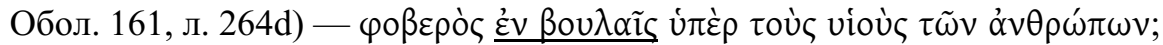

2. 128-129], в изучаемом памятнике представлено двумя примерами: а) в Пс. 14:5: Gревра своего не Аасть в́ рҺzы (Прян. 8, л. 19с; то же в Обол. 161, Л. 209а) -

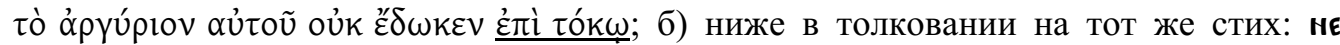

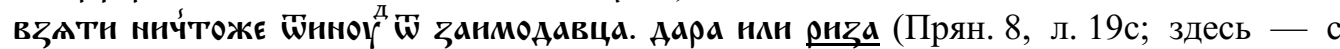

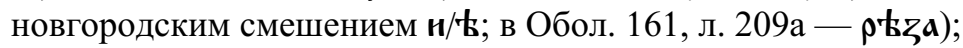

3. *мотъкъ: мотъцн w новомњслчьн (в толковании Исихия на Пс. 77:69 -

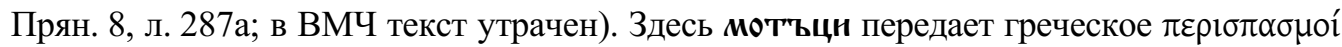
'то, что отвлекает внимание; отвлечение, рассеянность; заботы, хлопоты и т. п.' [PG 55: 721]. Слово не зафиксировано в словарях. Семантика переводимого грецизма заставляет предполагать связь с восточнославянизмом мотъчьннкъ 'мятежник, смутьян', известному по переводу Истории Иудейской войны, а также русскими диалектизмами моток 'легкомысленный, непостоянный человек', мотошник 'волокита, бабник’ и др. [Пичхадзе 2011: 120];

${ }^{15}$ Исправляю досадную оплошность, допущенную в [Вершинин 2017: 24]. Здесь фрагмент, в котором содержится лексема, определен как Пс. 10:4 (этот стих приводится ниже в переводе толкования Феодорита, но русизма не содержит). 
4. мнмєнь/мнм'нь 'гавань, $\lambda$ ıйv'. Данный грецизм известен почти исключительно по древнерусским текстам, а его наличие в поздних (тырновских) болгарских памятниках (известно всего три примера) может объясняться заимствованием [Пичхадзе 2011: 136; Молдован 2016: 78]. Встречается в переводе толкования Исихия на Пс. 53:9 (греческий оригинал недоступен): въ мнмънь покаАннА (Прян. 8, л. 101с); в ВМЧ - Анмень (Обол. 161, л. 243a);

5. гакорь - скандинавизм, известный только древнерусскому языку [Пичхадзе 2011: 88-89]. В рассматриваемом тексте служит глоссой к толкованию Исихия на Пс. 83:13: ан́когра во гакорь вох́ноүюцнмъ (Прян. 8, л. 304с; в ВМЧ текст утрачен) -

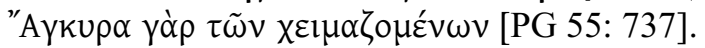

Нередки в тексте глаголы, построенные по восточнославянской модели (с суффиксом Ыва-/нва-): заБлоүжнваеть (Прян. 8, л. 110d; Обол. 161, л. 247a), ШмьГАА-

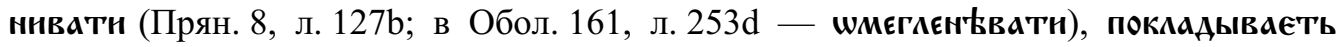
(Прян. 8, л. 14а; Обол. 161. л. 206b), постранваетє (Обол. 161, л. 251a; в Прян. 8, л. $120 \mathrm{~b}$ искажено - постраєваєте) и т. Д. Из морфологических русизмов следует особо отметить имперфекты с приращением: въыскахоүть (Прян. 8, л. 281а; в ВМЧ текст утрачен), коүшахоүтьсл (Прян. 8, л. 59а; в Обол. 161, л. 226d - шкоүша-

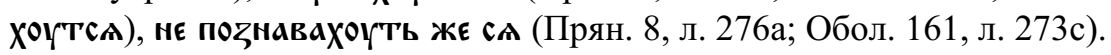

Наряду с восточнославянской лексикой памятник содержит характерные южнославянизмы, малоупотребительные в русской книжности: єтєръ, в том числе в значении 'другой' (многажды, напр. скинню етєрю Прян. 8., 43с; єтеры моүсикгискын ар́ганы 53а), нскрь (114b), прЊзорьство (114с), в рбснотоҮ (241b), шнъсаго (88d), шшють (69a). В этом отношении наш памятник также сближается с древнейшими русскими толковыми переводами - Толковым Евангелием Феофилакта Болгарского, Толковым Апостолом, толкованиями Никиты Ираклийского на слова Григория Богослова [Пичхадзе 2011: 32-34].

На протяжении всего текста для ввода библейских цитат или при их пересказе употребляется аорист вЊща (вместо стандартного рєчє древнеболгарских переводов), что является отличительной чертой русских домонгольских толковых переводов [Алексеев 1999: 178-179]. Интересно, что при этом в памятнике не встречается другое необычайно характерное для толковых переводов выражение а рєкоу 'то есть'; изредка используется лишь вариант рєкоү жє как буквальный перевод с греческого:

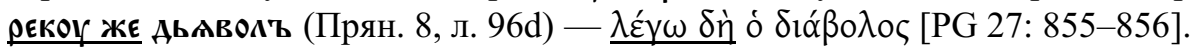

Нередки частотные [Пичхадзе 2013: 256-258] в толковых переводах наречия тачє

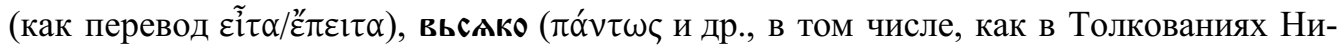
киты Ираклийского, в качестве перевода греческого ї $\sigma \omega \zeta$ в толковании Исихия на

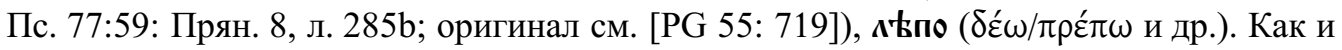
в других русских толковых переводах [Федорова 2017а: 252-260; Федорова 2017б], для ввода цитат иногда употребляется конструкция єжє то: Єжє то ащє смоу того ра

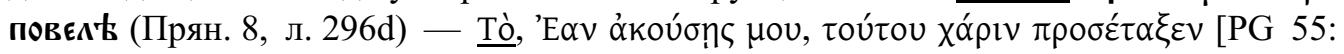
730]. Можно также отметить выражение како тн, присутствующее также в переводе Толкового Евангелия Феофилакта Болгарского [Федорова 2017a: 263-265; Федорова 
2017б]: почюднса како тн ш новъмъ ншснфъ въща (Прян. 8, л. 296а) -

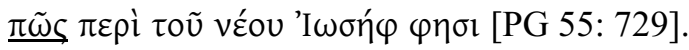

Вообще лексическое богатство памятника велико. В нем встречаются редкие

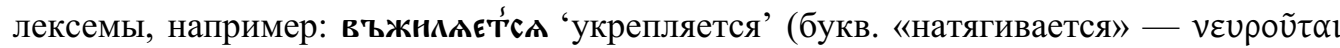
[PG 93: 1229]) (Прян. 8, л. 241b; Обол. 161, л. 259c) ${ }^{16}$, *гровърыга или *гроворыга 'вор, обкрадывающий могилы' (в Прян. 8, л. 113d - гровърыє; в Обол. 161, л. 248а гроворы) ${ }^{17}$. Особый интерес вызывает слово *n'шьна (ср. современное пешня),

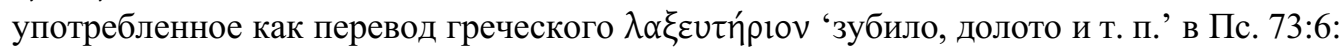
Въкоуп' съчнваны (!) н п'шьнамн рац̆рогшнша ${ }^{18}$ (Прян. 8, л. 264b; в Обол. 161, л. 268d - чєканы и с́п'ш́нами). В цитате из Быт. 21:28 вместо агнєць/агннць

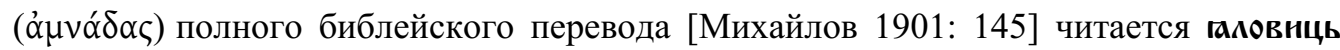
(Прян. 8, л. 90с; в Обол. 161, л. 238d) - это, вероятно, древнейший случай употребления данной лексемы ${ }^{19}$. Нередки слова, не зафиксированные историческими сло-

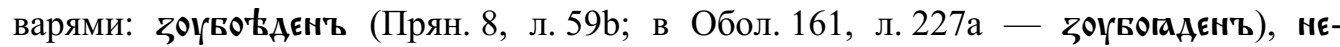
въсх́хаст'ноє 'неудержимое, необузданное' (Обол. 161, л. 249а; в Прян. 8, л. 116а -

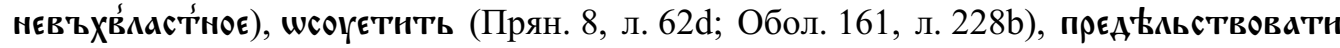
(Прян. 8, л. 241b; Обол. 161, л. 259c), профнтннъ (прочи́тп५) (Прян. 8, л. 92d; в Обол. 161, Л. 239d - протнфннъ), памодавєць (Прян. 8, л. 116b; Обол. 161, л. 249b) ${ }^{20}$, оүтровоқданна (Прян. 8, л. 99с; в Обол. 161 , л. 242c - оүтровошвь'Аанна), *хоудогоүють 'замышляют худое' (в Прян. 8, л. 101а - Х0догоують,

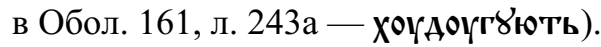

Еще одной яркой чертой, сближающей памятник с ранними древнерусскими толковыми переводами, является глоссирование некоторых слов. Подобные глоссы встречаются в Толковом Евангелии Феофилакта и Толковом Апостоле; единичные случаи отмечены и в других (не толковых) древнерусских переводах - беседах на Шестоднев Севериана Гавальского (этот перевод по языку примыкает к толковым), Хронике Георгия Амартола, Повести о Варлааме и Иоасафе, Житии Феодора Студита [Пичхадзе 2011: 75-77]. Вероятно, точнее вслед за А. А. Пичхадзе называть эти глоссы дублетами: некоторые из них предлагают не славянский перевод грецизма (что было бы естественным назначением глоссы), а, напротив, соответствующий славянскому слову грецизм в кириллической транскрипции. При этом глоссирование ряда слов «ничем не мотивировано», так что А. А. Пичхадзе выдвинула предпо-

\footnotetext{
16 Зафиксировано только в переводе февральской служебной минеи [Крысько 2009: 67].

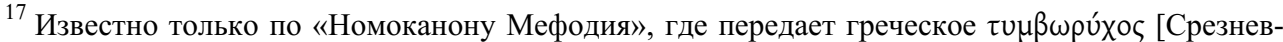
ский I: 594; Максимович 2009: 130].

${ }^{18}$ В рукописи ошибочно: рарац̆роүшнша (так!).

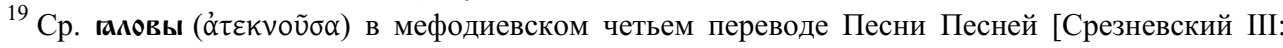
1656; Алексеев 1999: 88].

${ }^{20}$ Неверный перевод греческого $\Psi \alpha \lambda \mu \omega \delta$ ऽ̀, где вторая часть композита понята как производное от $\delta i ́ \delta \omega \mu$ ' 'давать'.
} 
ложение, что переводчики «работали с греческим текстом, записанным кириллицей» [Пичхадзе 2011: 75].

Ниже приводится полный перечень глосс (к странным «немотивированным» дублетам относится № 2). В Софийском списке ВМЧ их сохранилось больше, нежели в Прян. 8; почти все они располагаются на полях (кроме №№ 2-3 и 6). В Прян. 8 глоссы частью сняты, частью внесены в текст. В Успенском списке ВМЧ и в Егор. 12 отсутствуют все глоссы, располагающиеся на полях Софийской рукописи.

1. Zелні - маханъ (в Пс. 36:2):

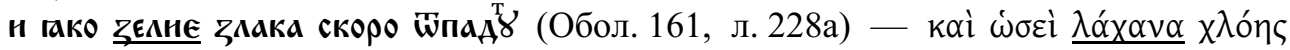
$\tau \alpha \chi \dot{v} \alpha \dot{\pi} \pi \varepsilon \sigma o \tilde{v} \tau \alpha$ [Rahlfs, Hanhart 2006: 36]; на правом поле глосса: маха[нъ]. В Прян. 8 глосса внесена в текст с потерей глоссируемого слова: ІАко паханъ зиакоу скоро вйадог (л. 62b).

2. ГАаГОлеть - АєГн (в толковании Исихия на надписание Пс. 53):

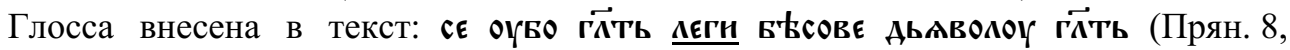
л. $100 \mathrm{~b}$, частично пропущено писцом и вставлено им через сноску на нижнем поле) -

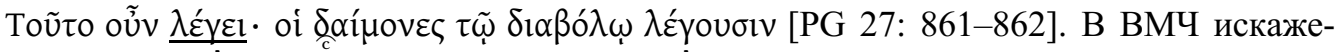

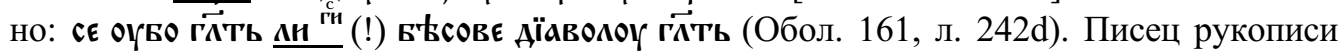
Кир.-Бел. 8/133 или ее протографа неверно понял эту глоссу, находясь под влиянием

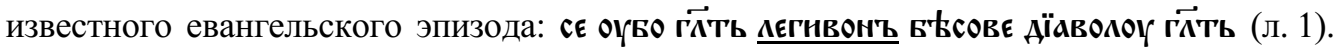
Позднейший читатель завершил переосмысление, исправив БЊсовє на БЊсовєскъ.

3. межюрҺчне - месопотамна (в толковании Исихия на надписание Пс. 59):

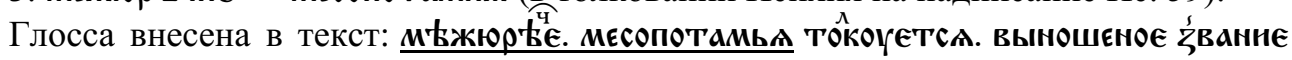

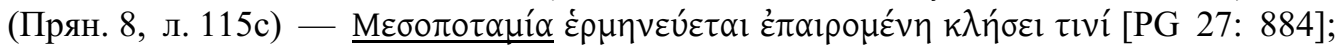
так же в ВМЧ (Обол. 161, л. 249a).

4. преторъ - ? (в толковании Исихия на Пс. 54:18):

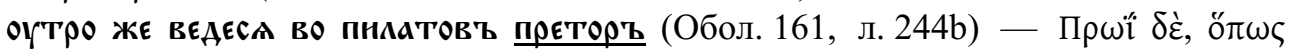

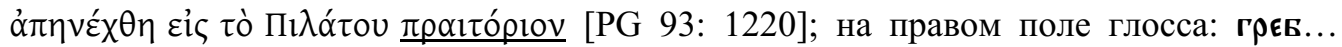
(окончание слова обрезано при переплете, виден хвост буквы ъ или $\mathbf{b}$ ). Отсутствие глоссы как в Прян. 8 (л. 164a), так и в Успенском списке ВМЧ (Син. 997, л. 351b) затрудняет восстановление загадочной лексемы. Если учесть, что слово прєторъ могло трактоваться отнюдь не в прямом смысле (например: «преторъ... а по-нашему темница» в хождении архимандрита Агрефения 1370-х гг. [ЭСРЯ III: 361]), допустимо видеть в данной глоссе образование от корня *greb-/grĕb- (ср. погрєвъ/ погрЊбъ, в т. ч. в значении 'темница').

5. скопєць - кажьннкъ (в толковании Исихия на Пс. 67:32):

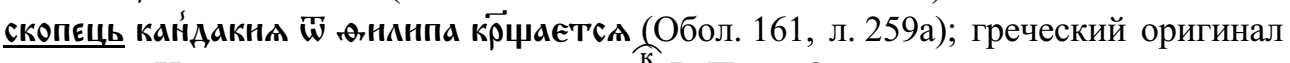
недоступен. На правом поле глосса: кажнн. В Прян. 8 глосса внесена в текст: скопець кажни (л. 240а).

6. артон - Хћњвн (в Мф. 4:3 в составе толкования Исихия на Пс. 68:11):

В обоих списках глосса внесена в текст: рцин да камєнне се воҮАоҮть артон

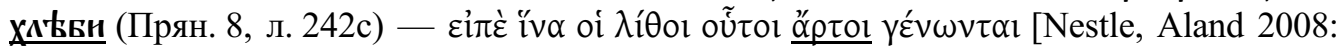


6-7]; греческий оригинал толкования Исихия недоступен. В ВМЧ артон отсутствует (Обол. 161, л. 259a).

7. тиноу — камъ (в пересказе Мих. 7:10 в составе толкования Исихия на Пс. $68: 15)$ :

вогАоуТЬ гако вор́ци перогџє тиноу (Обол. 161, Л. 260b); греческий оригинал недоступен. На правом поле глосса (другим почерком): и какъ. В Прян. 8 глосса внесена в текст: какъ тнноу (л. 243b).

8. ръвьнНКъ - КАаААҚЬ (в ПС. 68:16):

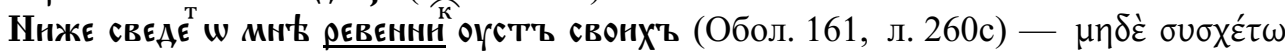

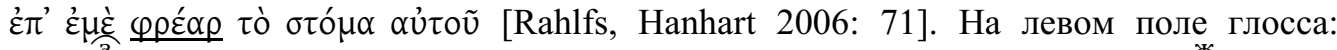
кмадА. В Прян. 8 глосса внесена в текст с потерей глоссируемого слова: Нн СвєАєТь

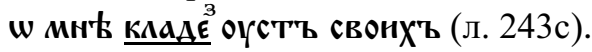

9. овразовъ - ст"њна (в толковании Исихия на Пс. 68:23):

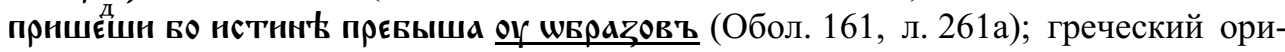
гинал недоступен. На правом поле глосса: or стьна. В Прян. 8 глосса внесена в текст: or стьна оу швразовъ (л. 245а).

10. анкогра - гакорь (в толковании Исихия на Пс. 83:13):

В Прян. 8 глосса внесена в текст: ан́коцра во гакорь вои́ногюцнмъ (л. 304c) -

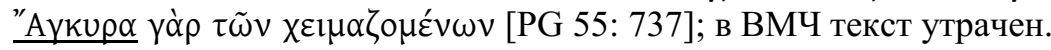

Глосса маханъ к слову ъєкнє встречается в переводе Толкового Евангелия Феофилакта [Пентковская, Индыченко, Федорова 2011: 43]. О связи нашего памятника с другими древними толковыми переводами свидетельствует и особое чтение в цитате Мф. 17:20 (в толковании Исихия на Пс. 67:29): ащє нмате вЊроҮ гако Ђер́но сннап́но...

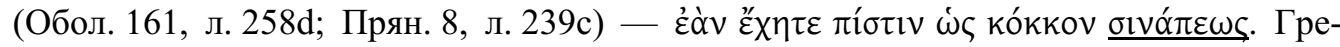
цизм сннапьно (вместо горюшьно) в составе этой цитаты зафиксирован в Толковом Евангелии и Толковом Апостоле [Пентковская, Индыченко, Федорова 2011: 46-48].

Ранняя датировка перевода подтверждается, наконец, комментарием к надписанию 6-го псалма — «о осмем» 'на восьмиструнном инструменте', где экзегеты издавна видели намек на «восьмую тысячу» лет - время после Второго пришествия Христова. Здесь во фрагмент перевода трактата Исихия «О надписании Псалмов» вместо абстрактной «шестой тысячи» вставлена конкретная дата:

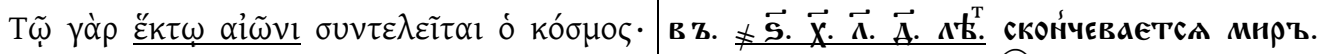

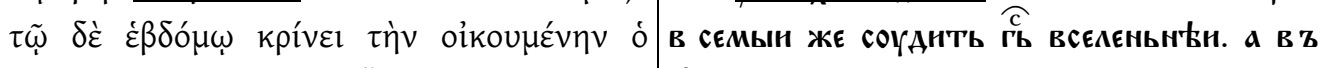

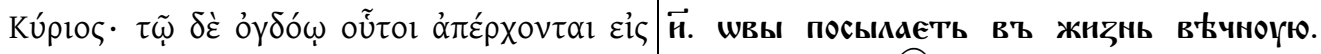

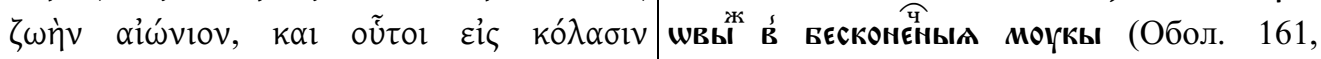

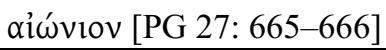
л. $202 \mathrm{~d})^{21}$

${ }^{21}$ В Прян. 8 (л. 7а) первая цифра даты выскоблена и заменена на з. Очевидно, переписчик принял это место за предсказание и, заметив, что указанная дата прошла, исправил ее. Кроме того,

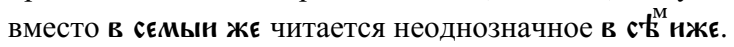


Ясно, что замена разрушила стройную экзегезу Исихия, где шестая тысяча лет обозначает настоящее время, седьмая - Второе пришествие, восьмая - «будущий век».

Дату 6634/1126 г. можно трактовать двояко: а) как обозначение времени, когда был создан перевод катены или его греческий антиграф (дата едва ли имеет отношение к архетипу катены, который должен датироваться значительно более ранней эпохой - компиляция не содержит никаких следов поздней византийской традиции); б) как выражение эсхатологических чаяний русского книжника (по предположению А. А. Гиппиуса, высказанному в устной беседе с автором этих строк, приведенная в катене дата могла восприниматься как вероятное время Второго пришествия: она вписывается в модель «год, следующий за n*100+33», где 33 - земной возраст Христа) ${ }^{22}$. В любом случае, несмотря на отсутствие древних списков, следует относить новооткрытый памятник к числу наиболее ранних переводов, выполненных на Руси и относительно точно датируемых концом XI — началом XII в.

В настоящее время можно указать один пример использования описанной катены русскими книжниками. В некоторых списках полного перевода «Краткого комментария» Псевдо-Исихия имеются вставки из нашего памятника (нам известно два таких списка: ГИМ, Чуд. 175, сер. XV в.; РГБ, МДА 23, 1459 г.. автограф Пахомия Логофета). В некоторых местах в текст попали надписания «Исихий», не понятые и искаженные переписчиками:

\begin{tabular}{|c|c|}
\hline & \\
\hline 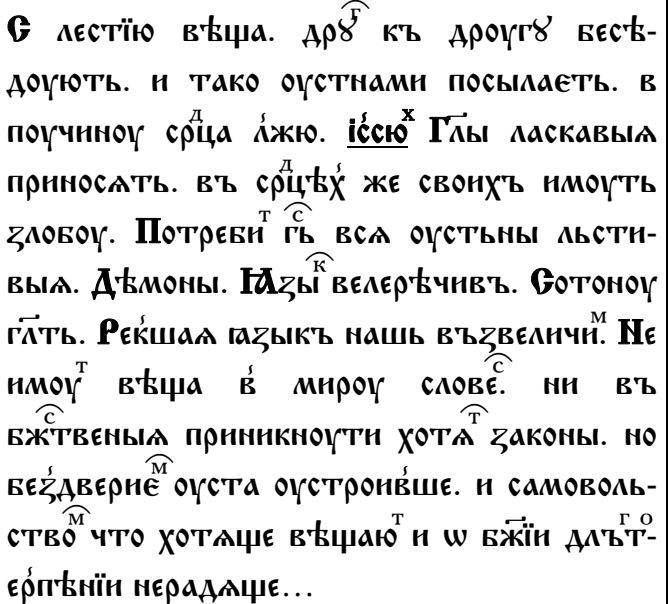 & 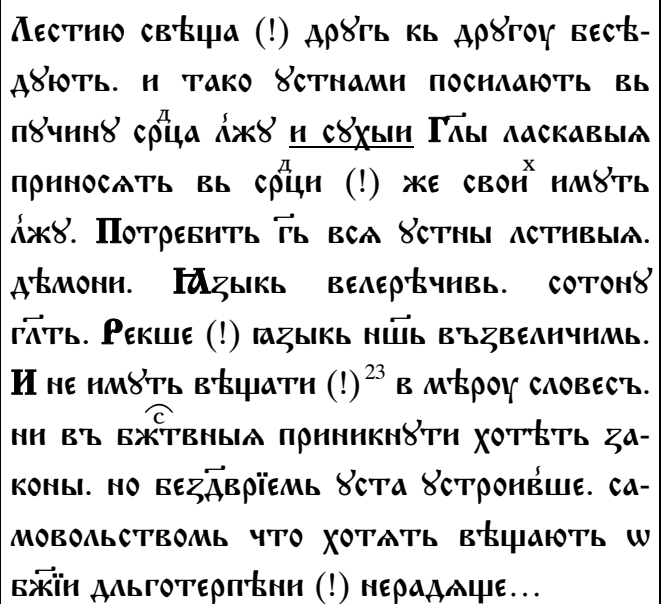 \\
\hline
\end{tabular}

22 Разумеется, Рождество Христово в данном случае датируется согласно «антиохийской» эре (5500 г.) Об эсхатологическом восприятии на Руси дат 6533/34 и 6537, рассчитанных по той же модели (в последнем случае прибавляются также три с половиной года земного владычества Антихриста) см. [Gippius 2013].

${ }^{23}$ Как видно, аорист вЊща вызывал затруднения если не у компилятора, то, во всяком случае, у писцов конкретных списков Псалтыри. 
Таким образом, отношения между двумя славянскими толковыми псалтырями взаимонаправлены. Переводчик катены черпал материал из полного текста ПсевдоИсихия; в свою очередь, древнеболгарский памятник на каком-то этапе рукописной традиции пополнился извлечениями из катены. Задачей будущих исследований должен стать, в частности, поиск других следов бытования этой катены в период более ранний, чем ее сохранившиеся списки.

Ниже публикуются два отрывка из новонайденного памятника (оба - с доступными греческими параллелями):

1) Пс. 14 с толкованиями Феодорита, Исихия и Псевдо-Исихия. В случае с Псевдо-Исихием приводится также текст соответствующих фрагментов из полного славянского текста «Краткого комментария» (по Болонской Псалтыри ${ }^{24}$ ), которым, повидимому, пользовался переводчик катены.

2) Пс. 51 с толкованиями Исихия, где надписание сопровождается фрагментом трактата «О надписании Псалмов», остальная часть - текстом «Большого комментария». Греческий оригинал «Большого комментария» на Пс. 51 опубликован лишь частично - в объеме фрагментов, вошедших в катены; впрочем, иногда этот оригинал оказывается пространнее славянского текста.

Толкуемый экзегетами псалтырный текст выделяется кавычками; номера стихов указываются в основных столбцах таблицы (в ряде случаев греческий текст дает иное, чем в славянском, сочетание стиха и толкования). Текст Псалтыри воспроизводится по изданию [Rahlfs, Hanhart 2006]. В левом столбце указываются источники других библейских цитат. Киноварь передается полужирным шрифтом.

\footnotetext{
24 Текст воспроизводится по фототипическому изданию [Болонски Псалтир 1968]. Не всегда высокое качество фотографий заставило нас сверить текст с наборным изданием [Jagić 1907: 55]. В передаче орфографии следуем рукописи (в этом отношении публикация И. В. Ягича отступает от оригинала - так, например, многие выносные буквы «спущены» в строку).
} 


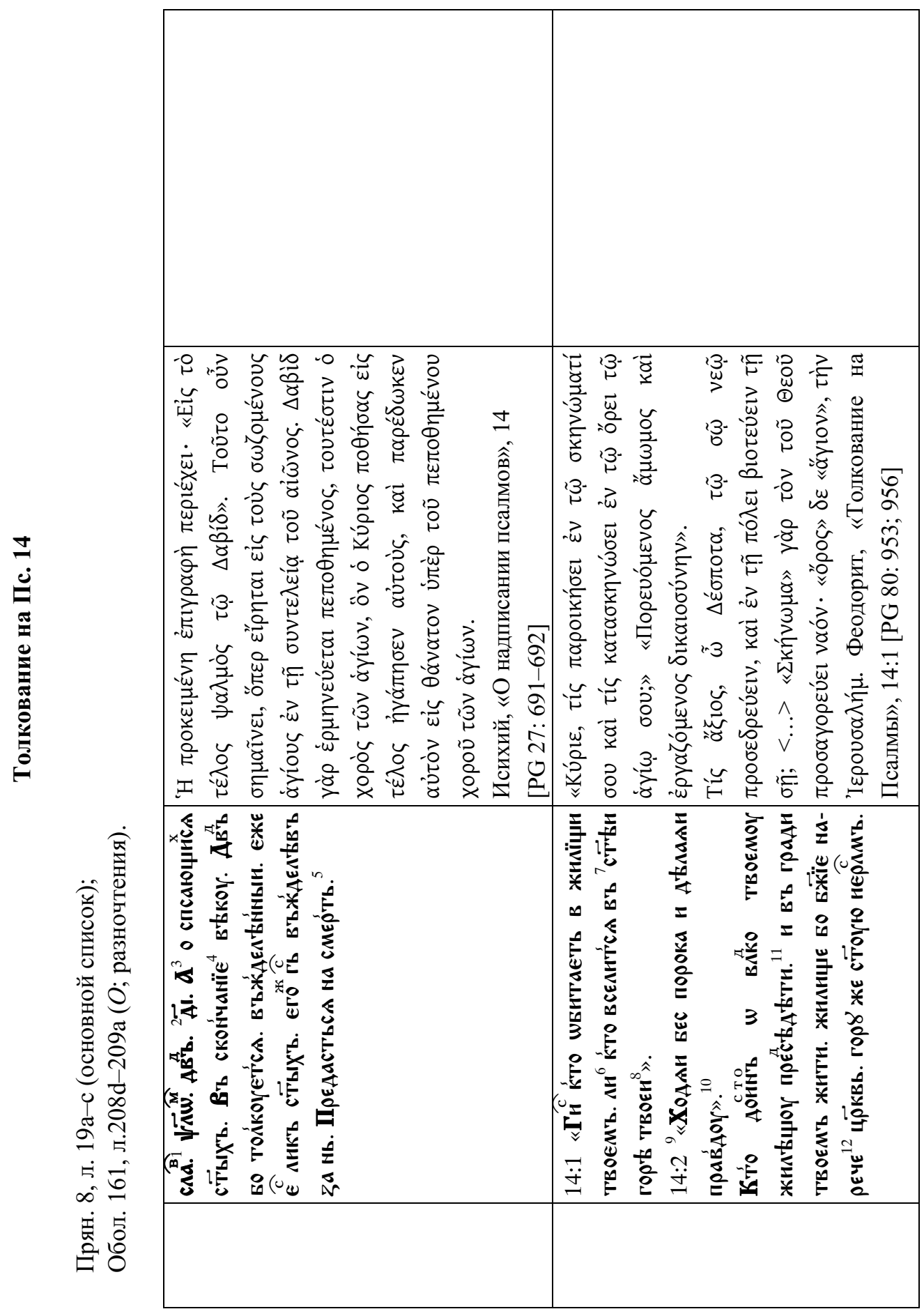




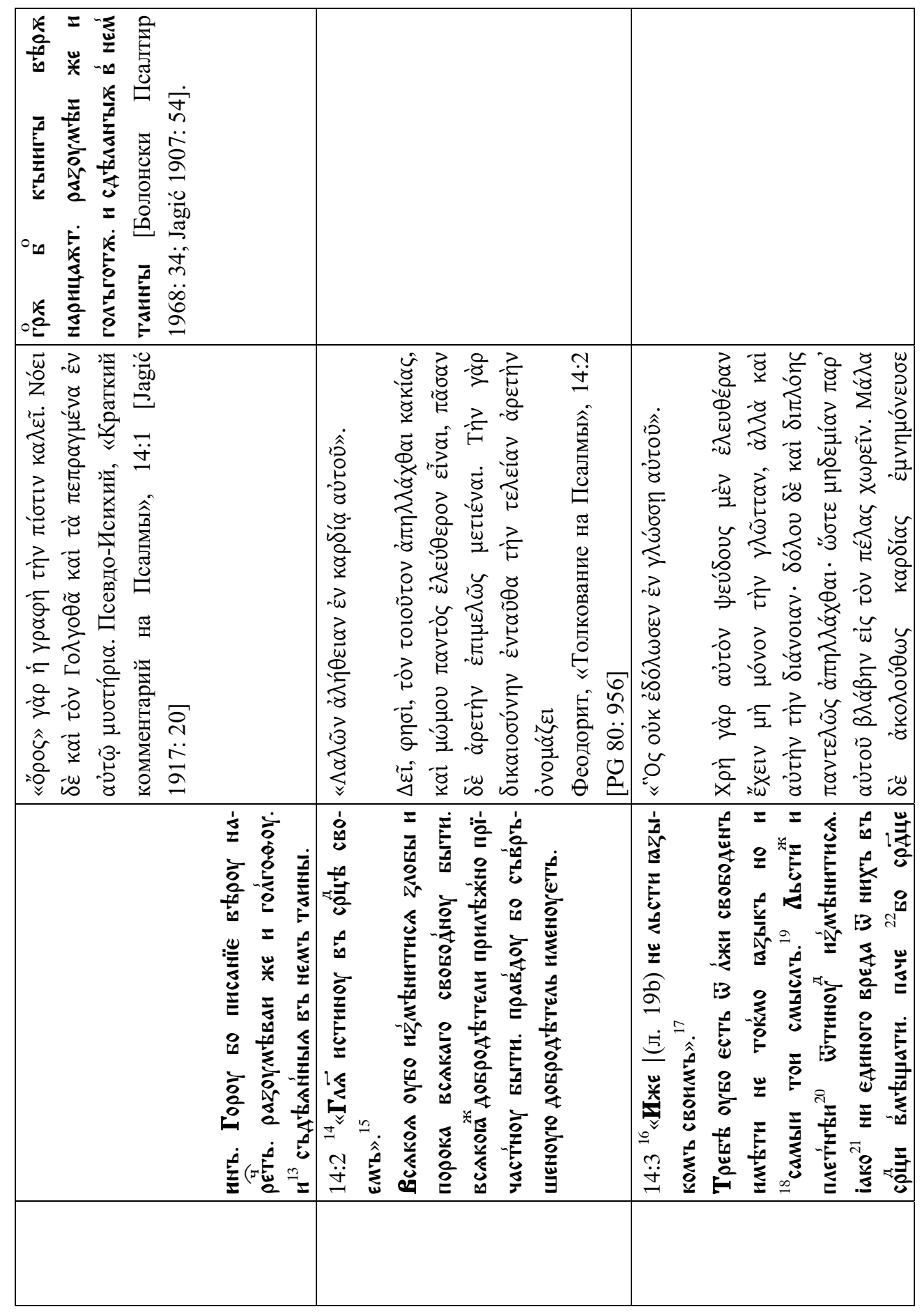




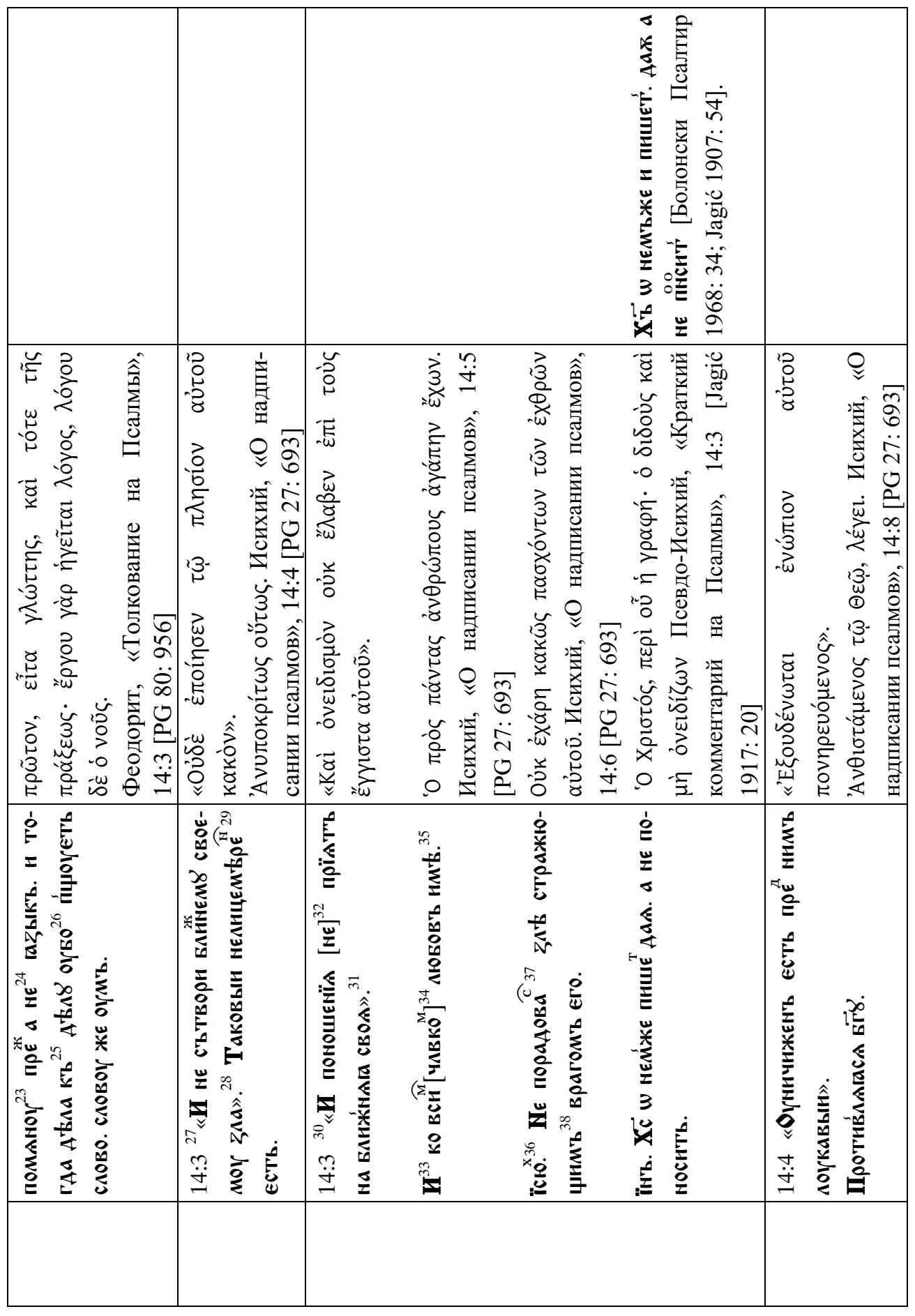




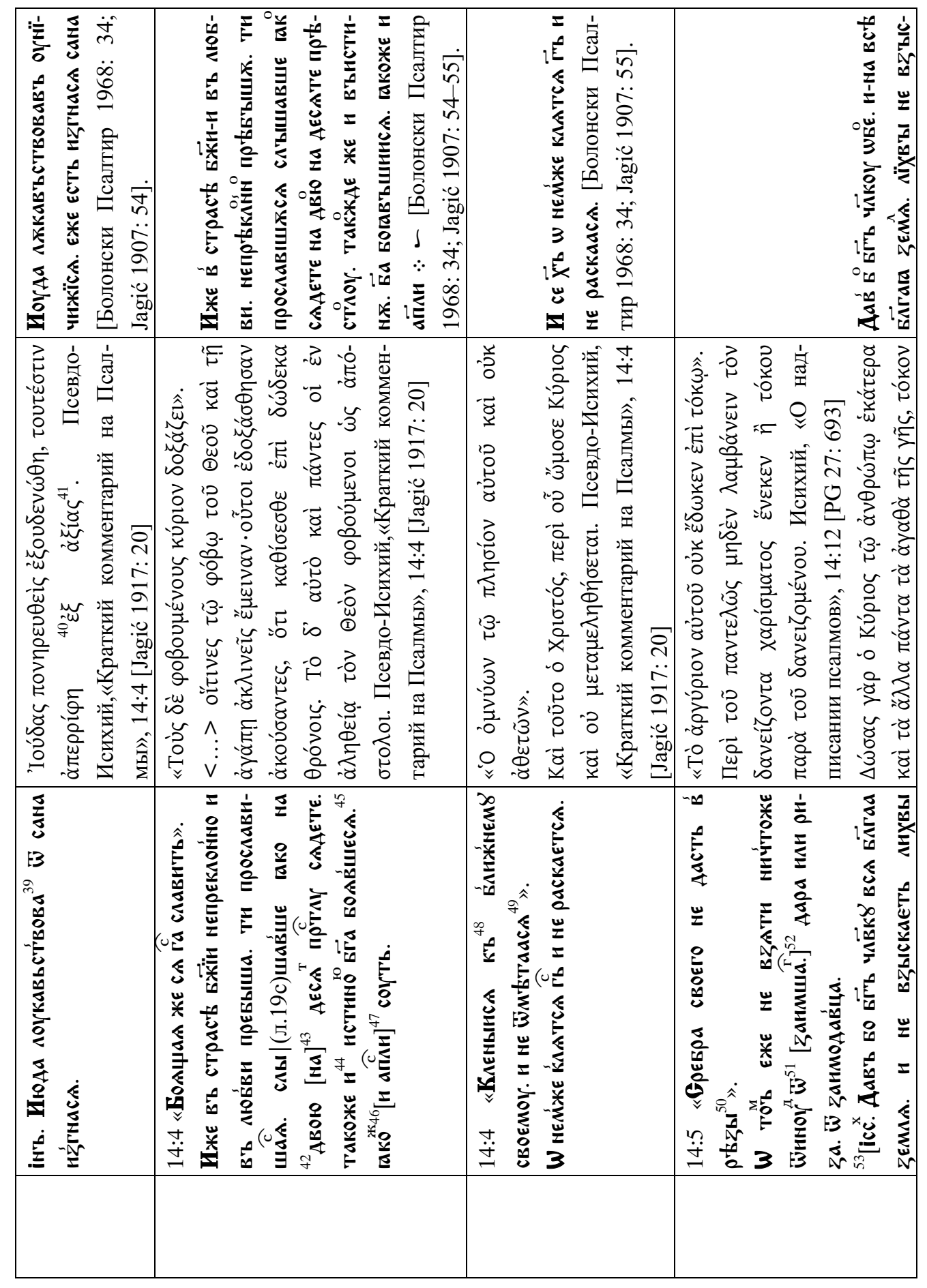




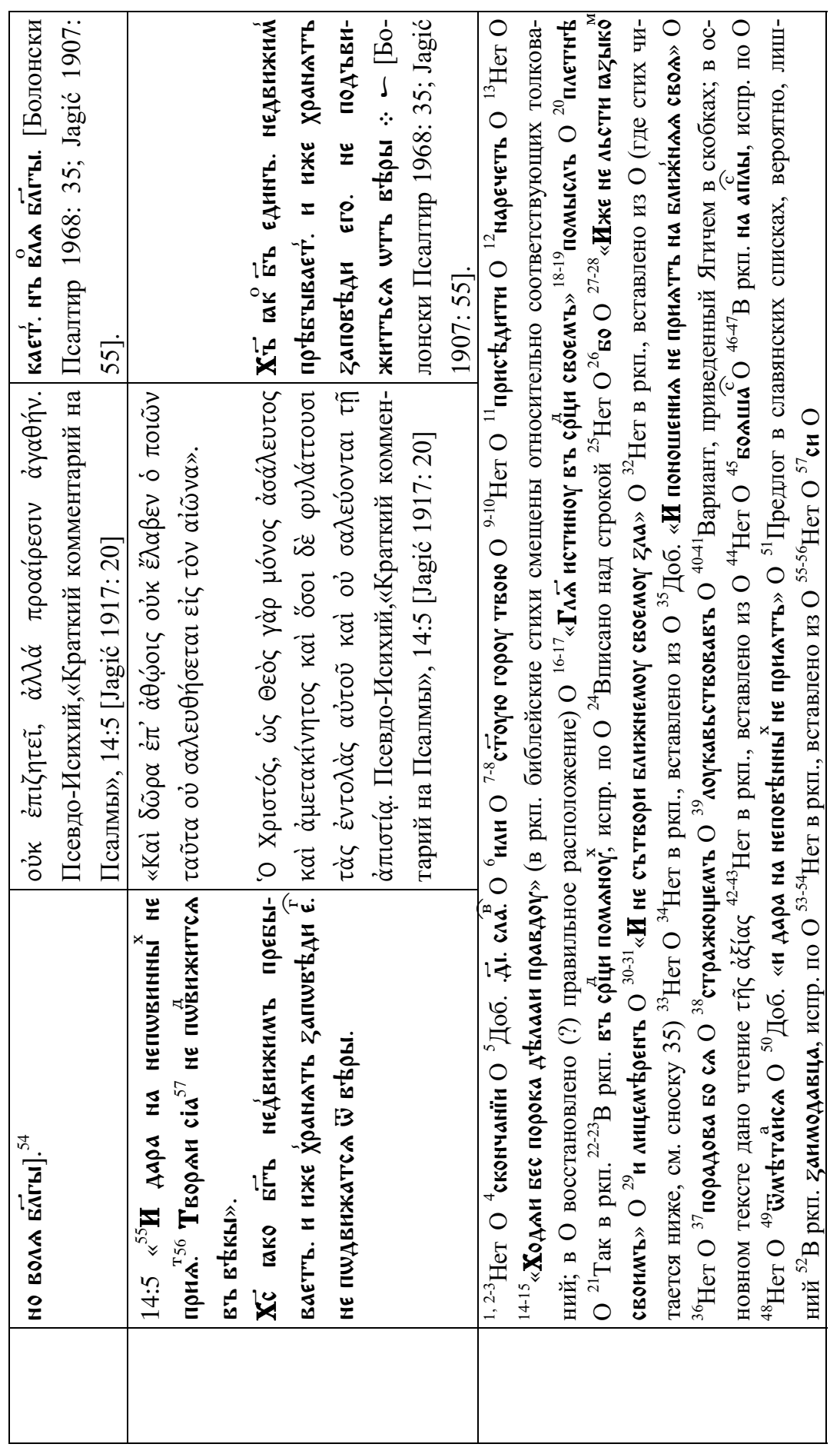




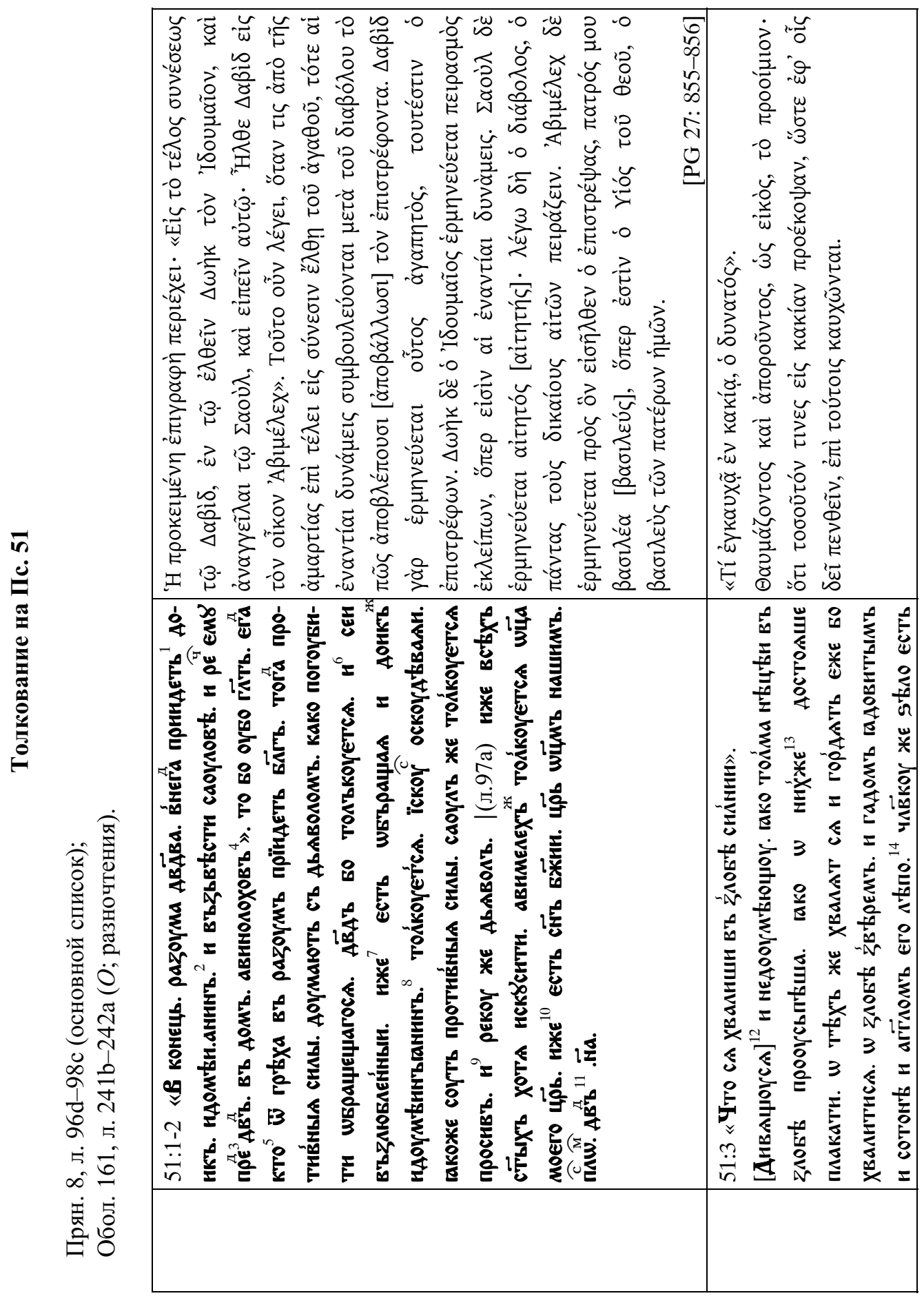




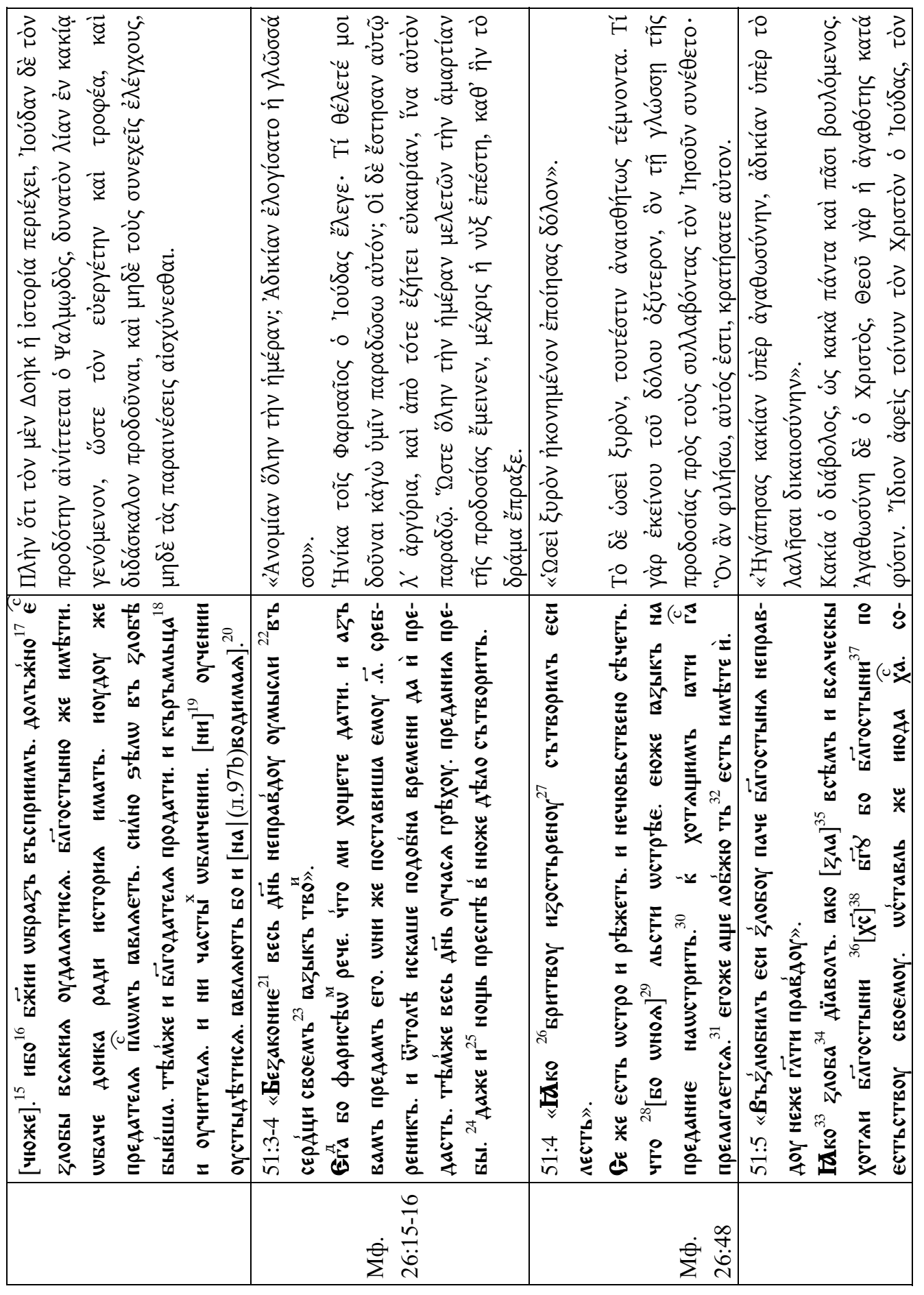




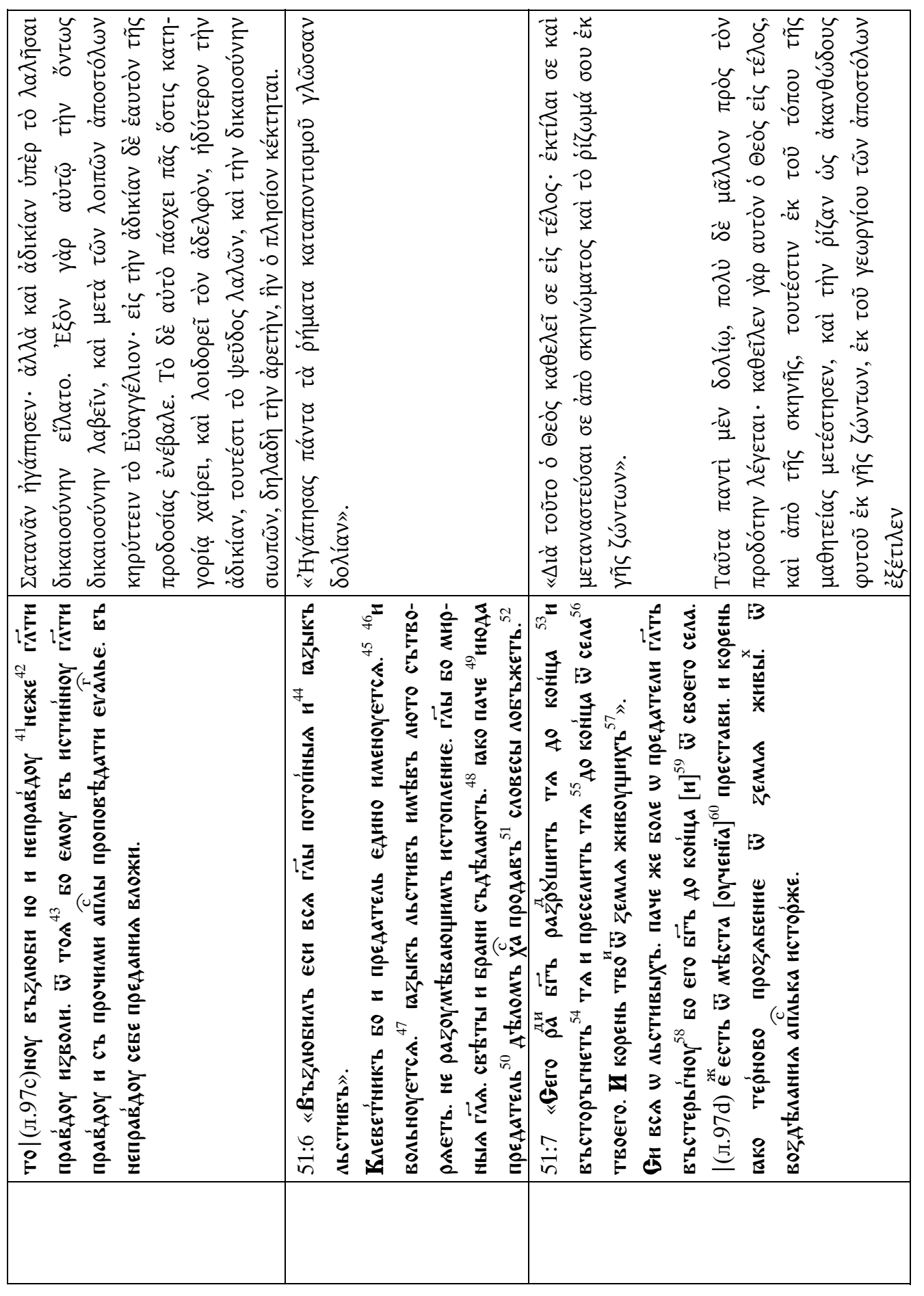




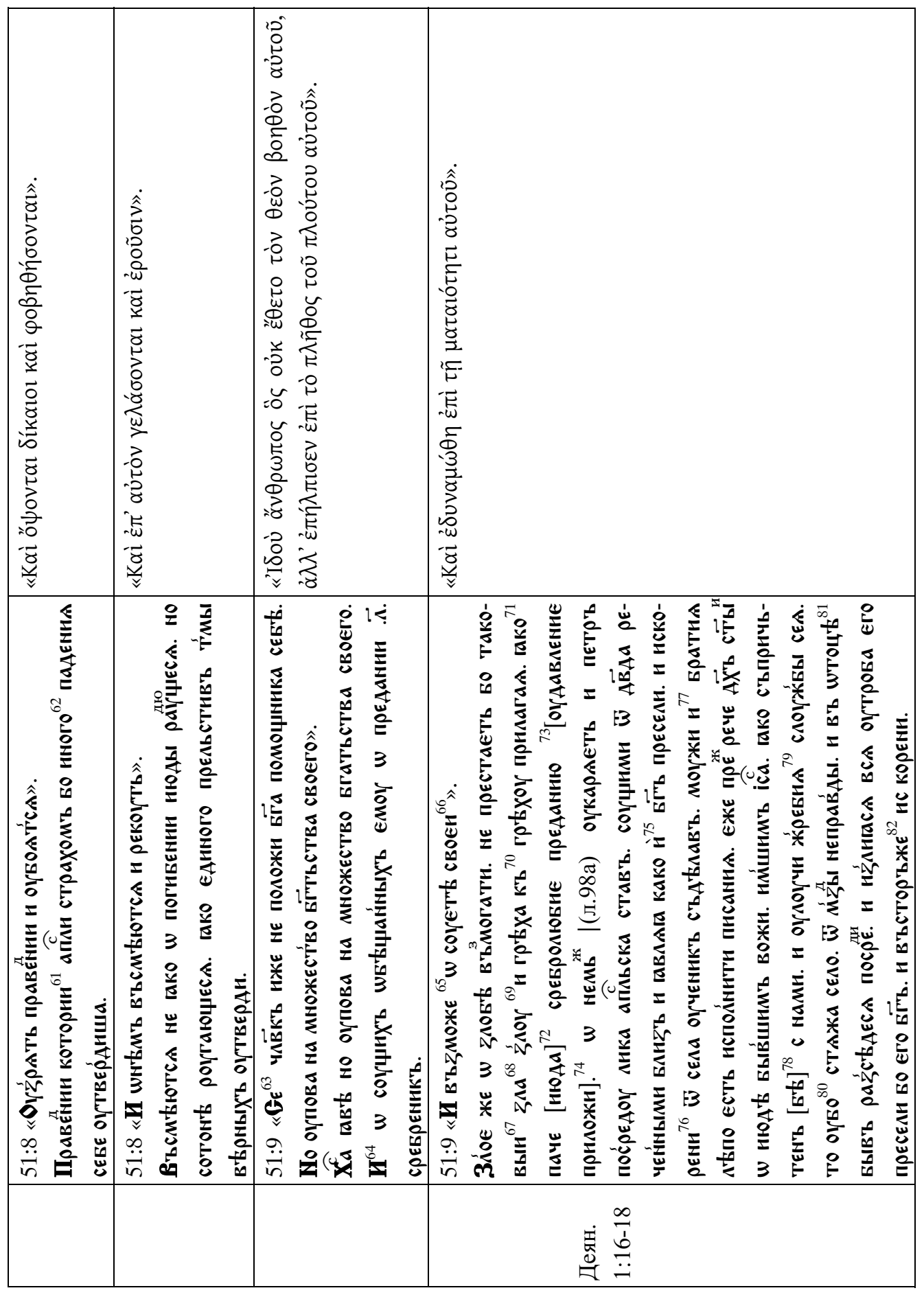




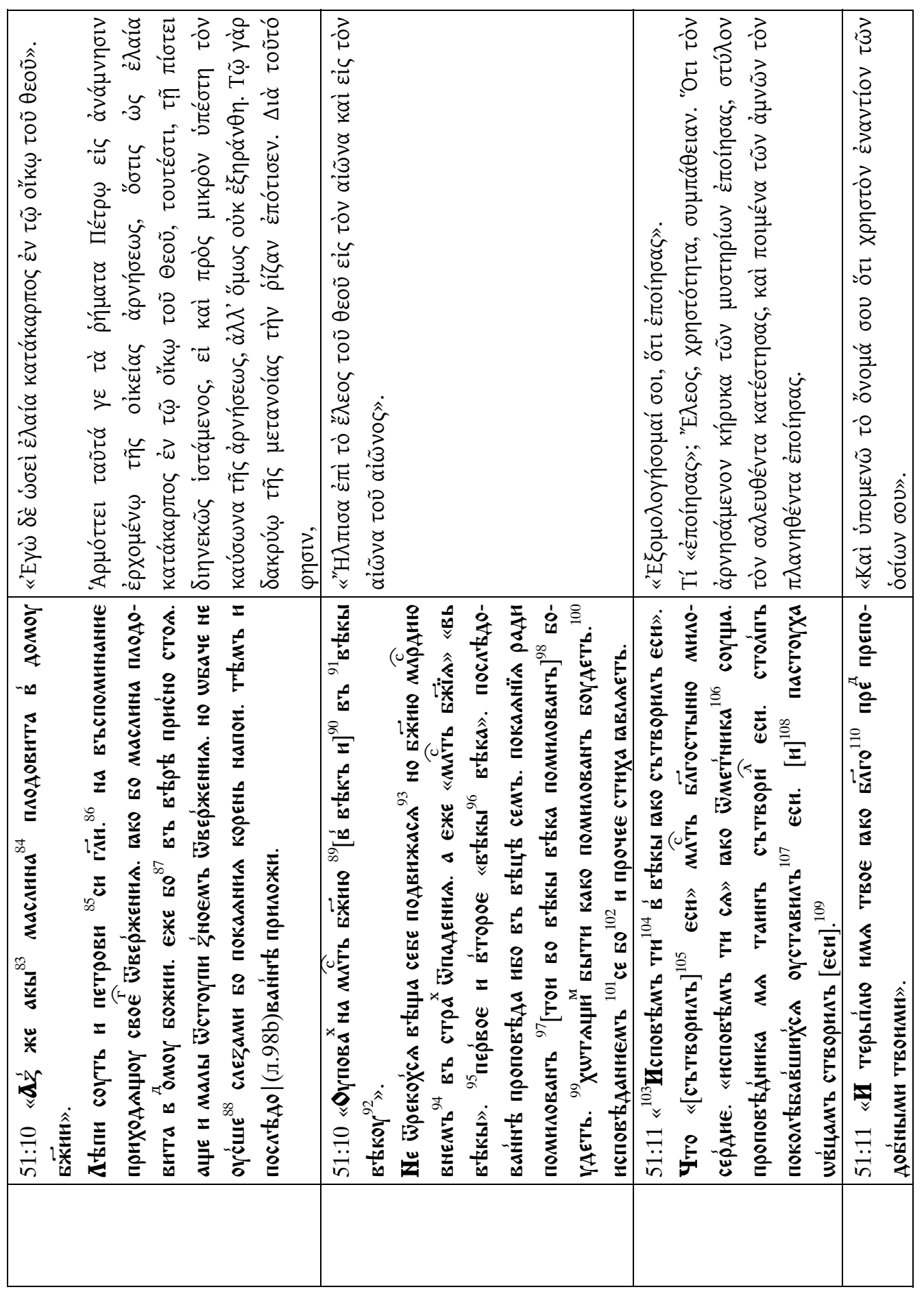




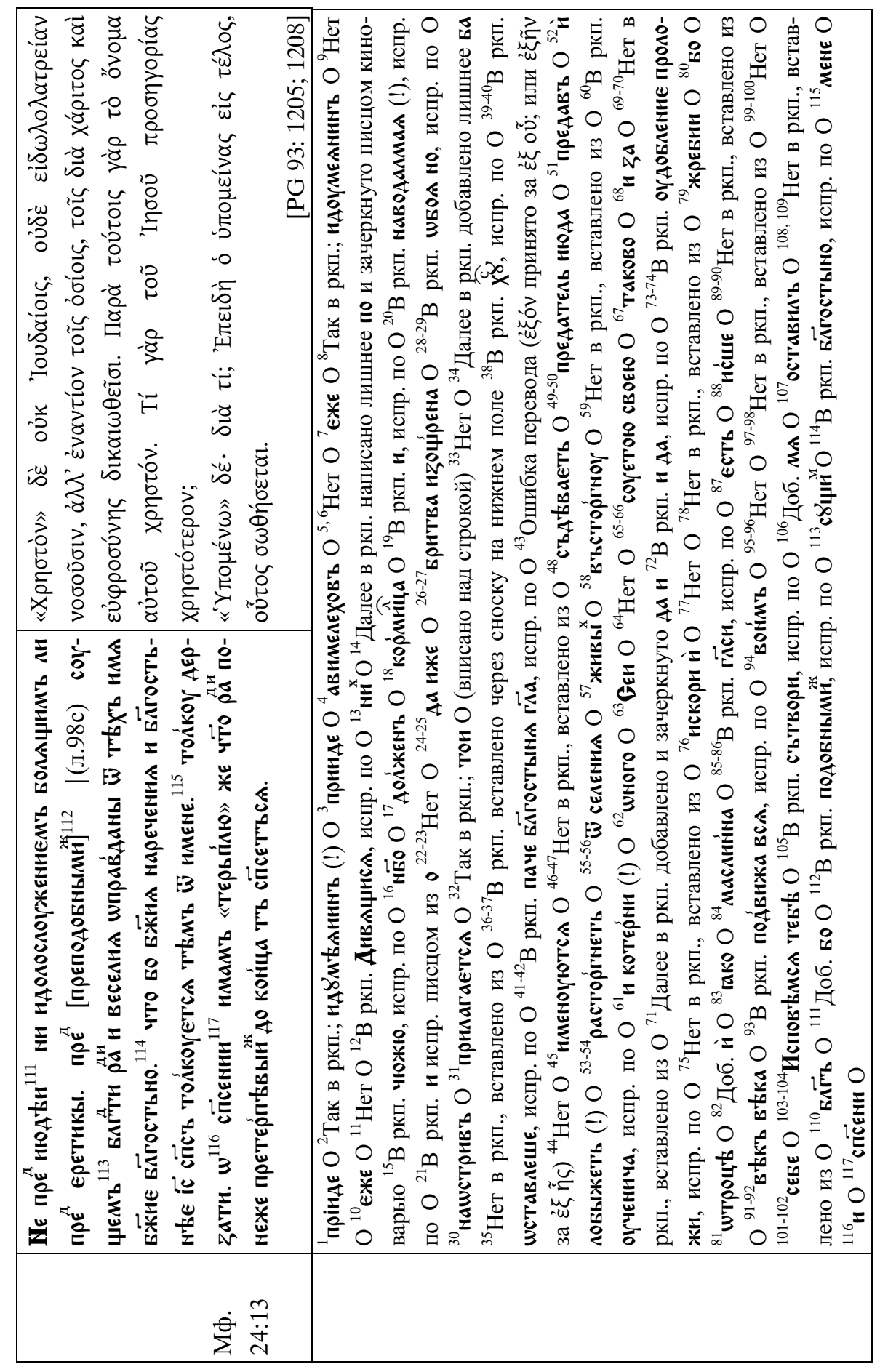




\section{Рукописные источники}

Кир.-Бел. 8/133 - РНБ, собр. Кирилло-Белозерского монастыря, № 8/133, толковая Псалтырь, 1430-е - 1440-е гг.

Егор. 12 - РГБ, собр. Е. Е. Егорова, № 12, сборник толковых Псалтырей, середина XVI в.

МДА 23 - РГБ, собр. Московской духовной академии, № 23, толковая Псалтырь, 1459 г.

Обол. 161 - РГАДА, ф. 201 (собр. М. А. Оболенского), Великая Минея четья (август), ок. 1538 г.

Прян. 8 - РГБ, собр. Г. М. Прянишникова, № 8, толковая Псалтырь, середина XVI в.

Рогож. 444 - РГБ, собр. Рогожского кладбища, № 444, толковая Псалтырь Феодорита Кирского, третья четверть XV в.

Син. 183 - ГИМ, собр. Синодальное, № 183, Великая Минея четья (август), середина XVI в.

Син. 997 - ГИМ, собр. Синодальное, № 997, Великая Минея четья (август), 1540-е гг.

Чуд. 175 - ГИМ, собр. Чудовское, № 175, толковая Псалтырь, середина XV в.

Roe 13 - Оксфорд, Бодлеанская библиотека, собрание Томаса Роу, № 13, сборник толкований на Псалтырь, 1284/1285 г.

Vat. gr. 525 - Ватиканская апостольская библиотека, греческое собрание, сборник толкований на Псалтырь, XI в.

Vat. gr. 1223 - Ватиканская апостольская библиотека, греческое собрание, сборник толкований на Псалтырь, Х в.

\section{Литература}

Алексеев 1999 - А. А. Алексеев. Текстология славянской Библии. СПб., 1999.

Анисимова $2017-$ T. В. Анисимова. Каталог славяно-русских рукописных книг из собрания Е. Е. Егорова. Т. 1. № 1-100. М., 2017.

Белокуров $1898-$ С. А. Белокуров. О библиотеке московских государей в XVI столетии. М., 1898.

Болонски Псалтир 1968 - Болонски Псалтир. Български книжовен паметник от XIII век. Фототипно издание с увод и бележки от Иван Дуйчев. София, 1968.

Бърлиева $2000-$ - С. Бърлиева. Московският препис на Дюканжовия списък // Старобългаристика/ Palaeobulgarica. 2000. № 3. С. 50-65.

Вершинин $2017-\kappa$. В. Вершинин Славянский перевод неизвестной катены на Псалтырь // Древняя Русь. Вопросы медиевистики. 2017. № 3 (69). С. 23-24.

Востоков $1842-A$. Х. Востоков. Описание русских и словенских рукописей Румянцевского музеума. СПб., 1842. 
Иосиф 1892 - Иосиф (Левицкий), архим. Подробное оглавление Великих Четиих Миней Всероссийского митрополита Макария, хранящихся в Московской Патриаршей (ныне Синодальной) библиотеке. М., 1892.

Крысько 2009 - В.Б. Крысько. Об издании февральской минеи // Russian Linguistics. 2009. № 1. C. 65-99.

Максимович $2009-$ К. А. Максимович Лексические и синтаксические кальки в моравском «Номоканоне Мефодия» // Русский язык в научном освещении. 2009. № 2(18). C. 125-143.

Михайлов 1901 - А. В. Михайлов. Книга Бытия пророка Моисея в древнеславянском переводе. Варшава, 1901. Вып. 2.

Молдован 2016 - А. М. Молдован. Восточнославянская лексика в переводе толкований Никиты Ираклийского на слова Григория Богослова // Труды Института русского языка им. В. В. Виноградова. Вып. 9. История русского языка и культуры. Памяти В. М. Живова. М., 2016. С. 70-85.

Пентковская, Индыченко, Федорова 2011 - Т. В. Пентковская, А. А. Индыченко, $E$. B. Федорова. К изучению толковой традиции домонгольского периода: Апостол и Евангелие с толкованиями // Лингвистическое источниковедение и история русского языка. 2010-2011. М., 2011. С. 30-51.

Пичхадзе 2011 - А. А. Пичхадзе. Переводческая деятельность в домонгольской Руси: лингвистический аспект. М., 2011.

Пичхадзе 2013 - А. А. Пичхадзе. Лингвистические особенности славянских толковых переводов XI-XII вв. // Письменность, литература, фольклор славянских народов. История славистики. XV Международный съезд славистов (Минск, 20-27 августа 2013 г.). Доклады российской делегации. М., 2013. С. 246-265.

Погорелов 1910 - Погорелов В.А. Толкования Феодорита Киррского на Псалтырь в древнеболгарском переводе. Варшава, 1910.

Протасьева 1970 - Протасьева T.Н. Описание рукописей Синодального собрания (не вошедших в описание А. В. Горского и К. И. Невоструева). М., 1970. Ч. І.

Срезневский I-III - И. И. Срезневский. Материалы для словаря древнерусского языка по письменным памятникам. СПб., 1893-1912. Т. I-III.

Ткачев $2011-$ E. В. Ткачев. Исихий Иерусалимский // Православная энциклопедия. М., 2011. Т. 27. С. 257-276.

Федорова $2017 \mathrm{a}$ - E. В. Федорова. Толковое Евангелие Феофилакта Болгарского в древнейшем славянском переводе: лингвотекстологический анализ. Дисс. ... канд. филол. наук. М., 2017.

Федорова $20176-$ E. В. Федорова. Из синтаксиса древнейшего перевода толкового Евангелия Феофилакта Болгарского: функционирование релятивизирующих частиц // Древняя Русь. Вопросы медиевистики. 2017. № 3 (69). С. 145-146.

ЭСРЯ - М. Фасмер. Этимологический словарь русского языка. М., 1986. T. I-IV.

Coxe 1969 - H. O. Coxe. Bodleian Library. Quarto Catalogues. I. Greek Manuscripts. Reprinted with corrections from the edition of 1853. Oxford, 1969. 
CPG - Clavis patrum graecorum. Turnhout, 1974-2003. Vol. 1-5.

Devreesse $1970-R$. Devreess.e Les anciens commentateurs grecs des Psaumes. Vaticano, 1970.

Dorival 1995 - G.Dorival. Les chaînes exégétiques grecques sur les Psaumes. Contribution à l'étude d'une forme littéraire. T. 4 (= Spicilegium Sacrum Lovaniense. Études et documents. Fasc. 46). Leuven, 1995.

Foss $1979-$ C. Foss. Ephesus after Antiquity: A Late antique, Byzantine and Turkish City. Cambridge, 1979.

Gippius 2013 - A. Gippius. "Gli ultimi cinque centenni" (6500-7000): sulla cronologia della escatologia antico-russa // I testi cristiani nella storia e nella cultura. Prospettive di ricerca tra Russia e Italia. Atti del convegno di Perugia - Roma, 2-6 maggio 2006 e del seminario di San Pietroburgo, 22-24 settembre 2009. Roma, 2013. P. 151-159.

Jagić 1907 - Jagić V. Gлов 'ынькага Псалътырь. Psalterium Bononiense. Vindobonae: Berolini: Petropoli, 1907.

Jagić 1917 - Jagić V. Supplementum Psalterii Bononiensis. Incerti auctoris explanatio psalmorum graeca. Vindobonae, 1917.

Nestle, Aland 2008 - Novum Testamentum Graece et Latine. Ed. Eb. et Er. Nestle, B. et K. Aland et al. Stuttgart, 2008.

PG - J. P. Migne. Patrologia Graeca. Paris, 1857-1866. Vol. 1-162.

Rahlfs, Hanhart 2006 - Septuaginta, id est Vetus Testamentum graece iuxta LXX interpretes. Ed. A. Rahlfs, R. Hanhart. Stuttgart, 2006. Vol. II.

\section{Konstantin V. Vershinin \\ Russian History Institute of the Russian Academy of Sciences \\ (Moscow, Russia)}

\section{AN UNKNOWN OLD RUSSIAN TRANSLATED \\ EXEGETICAL WRITING (CATENA ON THE PSALMS)}

The paper introduces a hitherto uninvestigated piece of Slavic translated literature: a catena on the Psalms, preserved in six copies of $15^{\text {th }}-16^{\text {th }}$ century (including three copies as parts of Metropolitan Macarius' Great Menaion Reader). The exact Greek archetype of the piece is unknown; the original volume of the translation is also unclear since surviving copies break off after Ps. 76 or in the middle of Ps. 84. The catena consists of fragments of four writings: Commentary on the Psalms by Theodoret of Cyrrhus (CPG 6202), On the Titles of the Psalms and Great Commentary on the Psalms by Hesychius of Jerusalem (CPG 6552, 6554), Brief Commentary on the Psalms by Pseudo-Hesychius (CPG 6553). Notably, the Great Commentary is presented by a nearly complete text of the exegesis of Ps. 51-84, which obviously should be considered in investigations of this important trac- 
tate, since its Greek original has been preserved only in few fragmentary copies. Analysis of the text demonstrates that the catena was translated by Russian bookmen in the late $11^{\text {th }}$ or early $12^{\text {th }}$ century. Its language is similar to that of other Old Russian translated exegetical writings, first and foremost to the Commentary on the Gospels by Theophylact of Bulgaria (of Ohrid) and to the Apostolos with Commentaries.

Key words: Hesychius of Jerusalem, Theodoret of Cyrrhus, Book of Psalms, catenae, exegesis, Old Russian literature, Slavic translated literature

\section{References}

Alekseev A. A. Tekstologiya slavyanskoi Biblii. St.-Petersburg, 1999.

Anisimova T. V. Katalog slavyano-russkikh rukopisnykh knig iz sobraniya E. E. Egorova. Vol. 1. No. 1-100. M., 2017.

Belokurov S. A. O biblioteke moskovskikh gosudarei v XVI stoletii. Moscow, 1898.

Bolonski Psaltir. B"lgarski knizhoven pametnik ot XIII vek. Fototipno izdanie s uvod $i$ belezhki ot Ivan Duychev. Sofiya, 1968.

B"rlieva S. Moskovskiyat prepis na Dyukanzhoviya spis"k. Starob"lgaristika / Palaeobulgarica. 2000. No. 3, p. 50-65. (In Bulg.)

Coxe H. O. Bodleian Library. Quarto Catalogues. I. Greek Manuscripts. Repr. with corrections from the edition of 1853. Oxford, 1969.

Clavis patrum graecorum. Turnhout, 1974-2003. Vol. 1-5.

Devreesse R. Les anciens commentateurs grecs des Psaumes. Vaticano, 1970.

Dorival G. Les chaînes exégétiques grecques sur les Psaumes. Contribution à l'étude d'une forme littéraire. T. 4 (= Spicilegium Sacrum Lovaniense. Études et documents. Fasc. 46). Leuven, 1995.

Fasmer M. Etimologicheskii slovar' russkogo yazyka. Vol. 1-4. Moscow, 1986.

Fedorova E. V. Tolkovoe Evangelie Feofilakta Bolgarskogo v drevneyshem slavyanskom perevode: lingvotekstologicheskii analiz. Diss. ... PhD. M., 2017.

Fedorova E. V. Iz sintaksisa drevneyshego perevoda tolkovogo Evangeliya Feofilakta Bolgarskogo: funktsionirovanie relyativiziruyushchikh chastits. Drevnyaya Rus'. Voprosy medievistiki. 2017, No. 3 (69), pp. 145-146. (In Russ.)

Foss C. Ephesus after Antiquity: A Late antique, Byzantine and Turkish City. Cambridge, 1979.

Gippius A. "Gli ultimi cinque centenni" (6500-7000): sulla cronologia della escatologia antico-russa. I testi cristiani nella storia e nella cultura. Prospettive di ricerca tra Russia e Italia. Atti del convegno di Perugia - Roma, 2-6 maggio 2006 e del seminario di San Pietroburgo, 22-24 settembre 2009. Roma, 2013, p. 151-159. (In Ital.)

Iosif (Levitskiy), arkhim. Podrobnoe oglavlenie Velikikh Chetiikh Miney Vserossiyskogo mitropolita Makariya, khranyashchikhsya v Moskovskoi Patriarshei (nyne Sinodal'noi) biblioteke. Moscow, 1892. 
Jagić V. Psalterium Bononiense. Vindobonae: Berolini: Petropoli, 1907.

Jagić V. Supplementum Psalterii Bononiensis. Incerti auctoris explanatio psalmorum graeca. Vindobonae, 1917.

Krys'ko V. B. Ob izdanii fevral'skoi minei. Russian Linguistics. 2009, No. 1, pp. 65-99.

Maksimovich K. A. Leksicheskie i sintaksicheskie kal'ki v moravskom «Nomokanone Mefodiya». Russkii yazyk v nauchnom osveshchenii. 2009, No. 2 (18), pp. 125-143. (In Russ.)

Mikhaylov A. V. Kniga Bytiya proroka Moiseya $v$ drevneslavyanskom perevode. Warsaw, 1901, No. 2.

Moldovan A. M. Vostochnoslavyanskaya leksika v perevode tolkovanii Nikity Irakliyskogo na slova Grigoriya Bogoslova. Trudy Instituta russkogo yazyka im. V. V. Vinogradova. Vyp. 9. Istoriya russkogo yazyka i kul'tury. Pamyati V.M. Zhivova. Moscow, 2016, pp. 70-85. (In Russ.)

Novum Testamentum Graece et Latine. Ed. Eb. et Er. Nestle, B. et K. Aland et al. Stuttgart, 2008.

Pentkovskaya T. V., Indychenko A. A., Fedorova E. V. K izucheniyu tolkovoi traditsii domongol'skogo perioda: Apostol i Evangelie s tolkovaniyami. Lingvisticheskoe istochnikovedenie i istoriya russkogo yazyka. 2010-2011. Moscow, 2011, pp. 30-51. (In Russ.)

Patrologia Graeca. Ed. J. P. Migne. Paris, 1857-1866. Vol. 1-162.

Pichkhadze A. A. Perevodcheskaya deyatel'nost' v domongol'skoi Rusi: lingvisticheskii aspekt. Moscow, 2011.

Pichkhadze A. A. Lingvisticheskie osobennosti slavyanskikh tolkovykh perevodov XIXII vv. Pis'mennost', literatura, fol'klor slavyanskikh narodov. Istoriya slavistiki. XV Mezhdunarodnyi s"ezd slavistov (Minsk, 20-27 avgusta 2013 g.). Doklady rossiyskoi delegatsii. Moscow, 2013, pp. 246-265. (In Russ.)

Pogorelov V. A. Tolkovaniya Feodorita Kirrskogo na Psaltyr' v drevnebolgarskom perevode. Varshava, 1910.

Protas'yeva T. N. Opisanie rukopisei Sinodal'nogo sobraniya (ne voshedshikh v opisanie A. V. Gorskogo i K. I. Nevostrueva). Moscow, 1970. P. I.

Septuaginta, id est Vetus Testamentum graece iuxta LXX interpretes. Ed. A. Rahlfs, R. Hanhart. Stuttgart, 2006. Vol. II.

Sreznevskiy I. I. Materialy dlya slovarya drevnerusskogo yazyka po pis'mennym pamyatnikam. Vol. I-III. St.-Petersburg, 1893-1912.

Tkachev E. V. Isikhiy Ierusalimskiy. Pravoslavnaya entsiklopediya. Vol. 27, Moscow, 2011, pp. 257-276.

Vershinin K. V. Slavyanskiy perevod neizvestnoi kateny na Psaltyr'. Drevnyaya Rus'. Voprosy medievistiki. 2017. No. 3 (69), p. 23-24.

Vostokov A. Kh. Opisanie russkikh i slovenskikh rukopisei Rumyantsevskogo muzeuma. St-Petersburg, 1842. 